\title{
PHILOLOGY, LITERATURES AND LINGUISTICS
}

\section{RESEARCH ARTICLES}

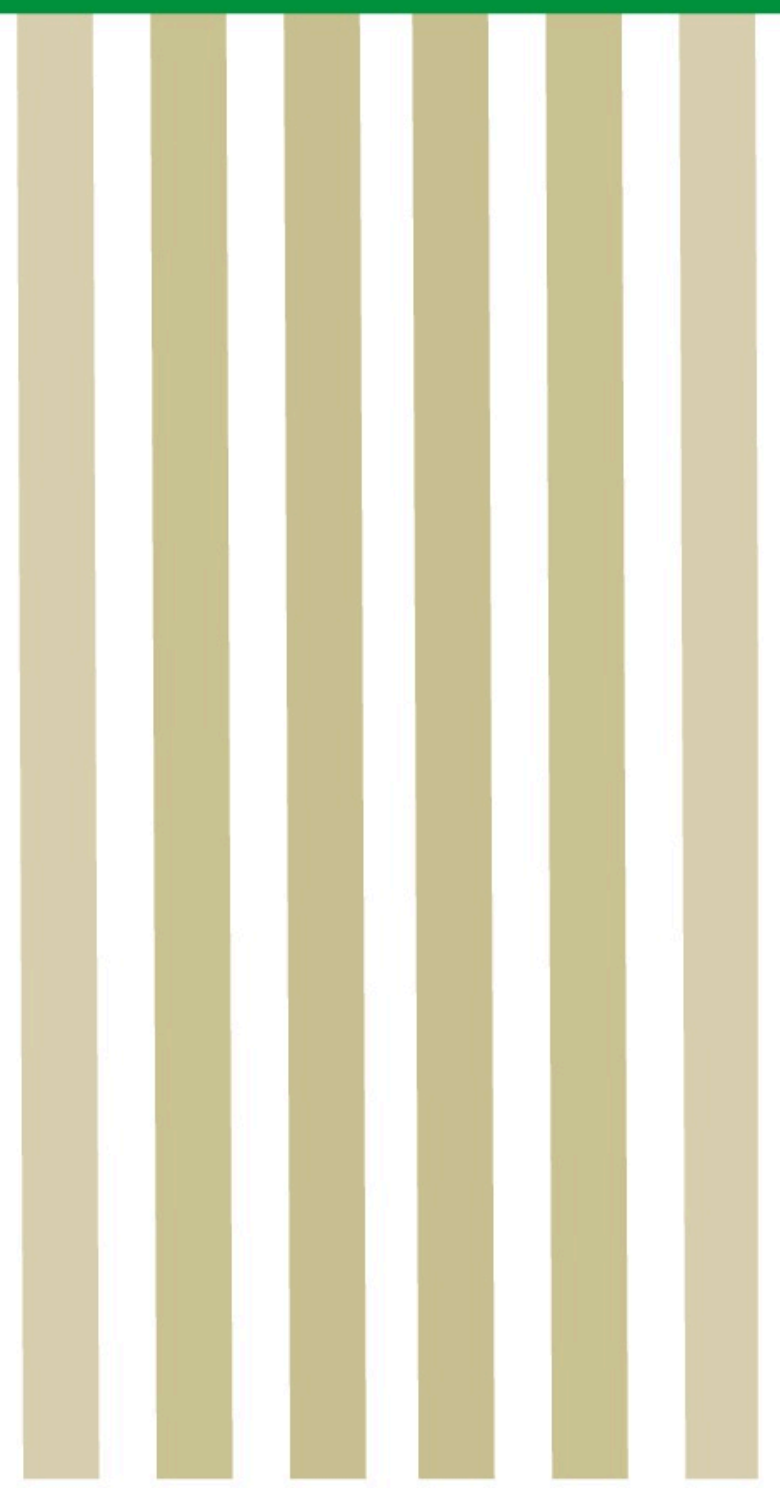

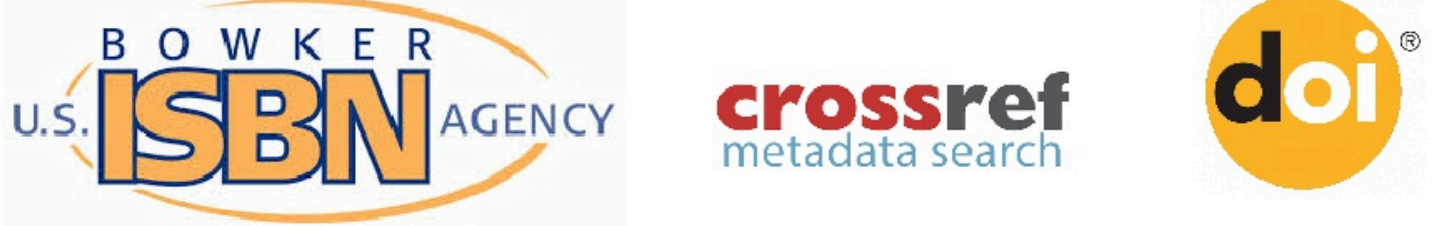




\section{PHILOLOGY, LITERATURES AND LINGUISTICS}

Research articles

B\&M Publishing

San Francisco, California, USA 


\author{
B\&M Publishing \\ Research and Publishing Center "Colloquium"
}

\title{
PHILOLOGY, LITERATURES AND LINGUISTICS
}

Science editor: R. Draut

Copyright (c) 2016

by Research and Publishing Center "Colloquium"

All rights reserved.

Published by B\&M Publishing.

San Francisco, California, USA
ISBN-10:1-941655-42-4

ISBN-13:978-1-941655-42-9

DOI: http://doi.org/10.15350/L_27 


\section{CONTENTS}

The translation of the poetry by S. Kunitz

L. Mosiyevych

"Day" and "Night" of F.I. Tyutchev's poetry: antinomies of poetic worldview

A. Valitov

8

Integration of psychological and philosophical concepts

M. Beksultanova in humanistic functions

R. Tataeva

Comparison as means of evaluation in banner advertising

T. Krutko

On the problem of literary translation in Karakalpak literary

T. Bayniyazova

Advantages of use of information technologies in the study of foreign

language

M. Hurramova

Features of the foreign language teaching not language high school

M. Bozorova

Competence approach study a foreign language in not language high school

N. Muradova

Pragmatic aspect of translation genre of tuyuq

Z. Shukurova

The symbolic-allegorical shapes in homilies Sulkhan Saba Orbeliani M. Khandzhalashvili

Household psychological principles in the works of Nodar Dumbadze I. Ardzhevanidze

The world of the future in Ray Bradbury's creativity

Sh. Vakhtangishvili

Nitssheanistic Messianism with georgian simbolists

N. Kochloshvili, T. Lapauri

For one kind of hypotactic construction in the Georgian language

E. Pilashvili

Karabakh war reflected in literature

V. Ibrahimova

The role of class staff in improvement of learning quality

A. Guliyev, G. Kazimova

Implicit methods for exspression of negation in modern Russian

F. Agakishiyeva

The concept "friendship" and its reflection in the English, Russian and Uzbek proverbs 
THE TRANSLATION OF THE POETRY BY S. KUNITZ

\section{Mosiyevych ${ }^{1}$}

DOI: http://doi.org/10.15350/L_27/01

\section{Absract}

The article presents the translational analysis of Kunitz's poetry into Ukrainian which has been made on the basis of the Ukrainian translation by B. Boychuk. The article is aimed at highlighting the main features of his poems and its peculiarities in the Ukrainian language translation. The poetry by S. Kunitz abounds in stylistic syntax and the Americanisms which nearly coincide with the Ukrainian variant.

Keywords: americanisms, free verse, inversion, repetitions, stylistic syntax, translation.

Modern poetry in America is marked by a constant struggle with the paradoxes of living in, with and through words. One of the most outstanding poet in America is S. Kunitz. He is considered by many observers to be the most distinguished and accomplished contemporary poet in the United States. The study of his poetic works is rather topical within the linguistic dimension. The translation of poetry is generally held to be the most difficult, demanding, and possibly rewarding form of translation. Kunitz's style is marked by transparency and simplicity of expression. But the simplicity of his poems is treacherous. His language is sophisticated, complex, and not easily translatable. A translator faces some difficulties because Kunitz's poems are characterized by free verse and a number of Americanisms. The goal of the article is to examine the main peculiarities of Kunitz's poetry and its translation techniques. The comparative analysis is used within that paper.

Free verse is an open form of poetry. It does not use consistent meter patterns, rhyme or any other musical pattern. It thus tends to follow the rhythm of natural speech [Abbs, p.137]. Although

\footnotetext{
${ }^{1}$ Larysa Mosiyevych, PhD, Associate Professor, Zaporozhye Classical Private University, Ukraine.
} 
free verse requires no meter, rhyme, or other traditional poetic techniques, a poet can still use them to create some sense of structure.

Free verse is poetry in its necessary freedom of expression and research. And one of the consequences of this is that it is as such the only place where the contemporary poet can define and solve the problems he meets in his existential or cultural condition [Scott 2000 , p. 45]. What the translator is attempting to do is not so much to translate a text, but to translate/transform the way a text lives, has its being, in the consciousness of a reader [Scott 2011, p. 75].

Stylistic syntax is the main feature of free verse [Scott 2002, p.211]. Kunitz's poems abound in repetition, anaphora, parallel constructions, inversion [Orr, p. 67]. The translator preserves those stylistic devices in the Ukrainian language, e.g. repetition:

\begin{tabular}{|c|c|}
\hline $\begin{array}{l}\text { I lie stretched out on a leaf, } \\
\text { Pale green on my bed of green, } \\
\text { Munching, munching [Кюніц, p. } \\
76] .\end{array}$ & $\begin{array}{l}\text { Я лежу, простягнувшись, на ли- } \\
\text { сточку, } \\
\text { Блідо-зелена на зеленім ложі, } \\
\text { Й жую, жую. }\end{array}$ \\
\hline
\end{tabular}

The rhetorical questions in the Ukrainian translation are also preserved:

\begin{tabular}{|l|l}
\hline $\begin{array}{l}\text { What makes the engine go? } \\
\text { Desire, desire, desire [Кюніц, p. } \\
\text { 36]. }\end{array}$ & $\begin{array}{l}\text { Фо є дия них рушієм? } \\
\text { Бажання, бажання, бажання. }\end{array}$ \\
\hline
\end{tabular}

Anaphora in source and target languages coincides:

So I have shut the doors of my house,

So I have trudged downstairs to my cell,

So I am sitting in semi-dark

Hunched over my desk... Кюніц,

p. 86].
Тож я позачиняв двері свого доMy,

Тож зійшов униз до комірки, Тож сиджу в півтемряві згорблений над столиком.
Draggling my life behind me in a sack

Naked I prow, scourged by the black [Кюніц, p. 96].
Я волочу в мішку життя марноване,

Повзу нагий і чорною спокусою. 
The stylistic device, inversion, in the Ukrainian translation from above, is not quite relevant to its source variant, nevertheless, the strict rhythm in Ukrainian is preserved.

There are some examples of Americanisms in Kunitz's poetry. Americanism is a word or meaning that is common in U.S. English but is not common in the kinds of English spoken outside the U.S. [Merriam-Webster's Learner's Dictionary]. A translator should be on the alert and choose the American English equivalent:

That single Model A sputtering up the grade unfurled a highway behind [Кюніц,, p. 24].
Машина моделі А, що тарахкоче вгору, промощує за собою шиях....

The American word highway is translated into Ukrainian not by the American meaning "шосce" but by a generalized word "ШАях" (Eng. Way).

In the next example the word purse is translated by the American meaning "a woman's handbag". But in the other poem we can see the translation of purse by the British meaning "a small bag for carrying money":

If I can gather strength enough I'll try to burrow under a stone And spin myself a purse [ Кюніц, р. 78].
Якщо я зможу ще зібрати досить сил, спробую заритися під камень і виткати собі торбиHy....

More even than my purse, And that's no laughing matter, it is my pride That has been hurt [Кюніц, p. 94].

The shift from American to British meaning in translation in the second example is quite relevant because the author says pride is more valuable than money.

The translator used the correct Ukrainian correspondence for the following Americanism "baggage" but with a slight archaic shade (обоз, in English cart, that is a vehicle pulled by a horse): 
Thanks to your lightfoot genius No Eighth Route Army kept its lines more fluid, Traveled with less baggage [Кюніц, р. 102].

\author{
Через твій прудконогий геній \\ жодна Восьма Похідна Армія \\ Не мала плинніших міній, насту- \\ пала з мегшим обозом.
}

The translator chose the American meaning for the word "stoop" which means "a raised area outside the front door of a house" in comparison with the British meaning "a way of standing or walking with your head and shoulders bent forwards and downwards":

\begin{tabular}{|l|l|}
\hline $\begin{array}{l}\text { I am not ready yet and nobody } \\
\text { stands on the stoop.... [Кюніц, p. } \\
122] .\end{array}$ & $\begin{array}{l}\text { Я ще не готовий, I ніхто там на не чекає... } \\
\text { пороз не че }\end{array}$ \\
\hline
\end{tabular}

Conclusions: The translator managed to preserve the peculiarities of Kunitz's free verse in the Ukrainian language. He matched the relevant stylistic devices to convey the strict rhyme, the intonation and the total image of a poem. The translation of the Americanisms caused a number of problems. In some cases the translator used not the American but British correspondences, but those options were quite stylistically and semantically reasonable.

\section{References:}

[1] Abbs P. The Forms of Poetry: A practical study guide for English / P. Abbs, J. Richardson. New York: Cambridge University Press, 1992. p. 137.

[2] Gregory Orr. Stanley Kunitz: An Introduction to the Poetry / Orr G. Columbia University Press (New York City), 1985. 297 p.

[3] Scott, Clive. Free Verse and the Translation of Rhythm. In: Thinking Verse I (2011) / C. Scott. [Electronic resource]. Mode of access: www.thinkingverse.com

[4] Scott, Clive. Translating Baudelaire. Exeter: University of Exeter Press, 2000. p. 287.

[5] Scott, Clive. Translating Free Verse: Jaccottet and Auden, Channel Crossings: French and English Poetry in Dialogue / C. Scott. Oxford: Legenda, 2002. pp. 209-238.

[6] Merriam-Webster's Learner's Dictionary [Electronic resource]. Mode of access: - http://www.merriam-webster.com/dictionary/Americanism

[7] Кюніц С. Творець відображень: Зб. поезій / Пер. з англ. К.: Факт, 2003. $136 \mathrm{c}$. 
"DAY" AND "NIGHT" OF F.I. TYUTCHEV'S POETRY: ANTINOMIES OF POETIC WORLDVIEW

\section{A. Valitov ${ }^{1}$}

DOI: http://doi.org/10.15350/L_27/02

\section{Abstract}

The article is dedicated to the study of the poetic space of Tyutchev's lyric poetry, which stands out in the wider context of the Russian poetic traditions of the XIX century for its "otherness". Though based on the ontological foundation upon which the ethical framework of the classical art was built, Tyutchev's lyric poetry clearly manifests the elements of the general perception of being that indicate the existential crisis, decay of former ontological principles, anticipating the emergence of a new cultural space - the poetry of the Silver Age.

Keywords. Tyutchev, "Day and Night", chaos, cosmos, paradoxical, metatext, Silver Age.

In 1883 - ten years after the death of F.I. Tyutchev - his younger contemporary, poet Afanasy Fet, wrote about a book of poems by Tyutchev whom he "adored":

\section{Here is our patent of nobility - Graciously granted by the poet, With reign of powerful spirit And bloom of sophisticated life.}

So, according to A. Fet, not only the refinement of the poet's lyrical voice but also its ultimate power is amalgamated in his verses. Thus A. Fet in his view of Tyutchev's poetry links two qualities which could seem almost incompatible.

However, the totality of the poetic space of Tyutchev's lyric poetry in its individual manifestations is characterized by even greater

\footnotetext{
${ }^{1}$ Andrei Valitov, Cand. Sci. (Philology), Associate Professor, K.D. Ushinsky State Pedagogical University, Russia.
} 
heterogeneity. Relying on the poetics only, it may be impossible to reconstruct the poet's integral world outlook, taking into account the wide semantic scope of his works - from the ancient heroics ("Cicero (Ciceron)", 1830) and Orthodoxy ("Oh, my prophetic soul! (O veshhaja dusha moja...)", 1855) to ontological nihilism ("Of life that blossomed here (Ot zhizni toj, chto bushevala zdes'...)", 1871).

Let us analyse the poem "Day and Night" (Den' i noch'), 1839.

The spirit world we may not see, That nameless gulf, is shrouded over And hidden by a golden cover; Thus do the gods on high decree. Day - this most splendid shroud is thee, Day - for us mortals, animation, The ailing soul's alleviation, That men and gods delight to see!

But let day fade and night commence; The blessed veil is torn, revealing The fateful world it was concealing, And hurled incontinently hence... The gulf lies naked to the sight With its black horrors of perdition, 'Twixt them and us lies no partition: And that is why we fear the night!

In his analysis of the poem, contemporary researcher M.M. Dunaev identifies some of the features of the inner world of Tyutchev, "Tyutchev expressed the pagan perception of the world - let us not try to determine now whether it was his actual worldview or just a poetic fantasy, an experience of "other-worldly" mental state. Paganism, usually credited with a harmonious interaction with the natural world, actually perceives it - and the universe as a whole - as something fraught with the horror of an incomprehensible mystery of fate. It is no wonder that the world in the Tyutchev's poem is "fateful". The day (light) is only a deceiving cover hiding the reality: fear and gloom. Gloom, darkness, absence of light - that's true pagan sensation of the surrounding world."[1, pp. 363-365]

In his further analysis of Tyutchev's poetry, M.M. Dunaev notes that the poet was able "to discern sinful conflicting states, concealed 
in the deepest depths of the soul and madly gravitating towards shapeless nothingness - chaos", and the researcher considers that the causes of such sensitivity were in instability, duality of the "true nature of Tyutchev himself"[2, p. 365 and 369].

Such characteristics of Tyutchev's lyrical poetry have been marked by many literary critics and scholars at different times. Thus, D.S. Merezhkovsky, for example, generally tended to maximize the importance of the internal sense of distress in the poets' works. N.N. Skatov wrote in this connection: "For Merezhkovsky, Tyutchev was, first of all, a carrier of the elements of individualism with all the related contradictions - from self-idolization to personal selfdestruction. 'Two forces drive the human world, as well as the world of the elements: attraction and repulsion of atoms - personalities. Of these two forces only one - the repulsive force - is affirmed by Tyutchev.' '... Buddhism is a religion of inaction. It is primarily a religion of contemplation. This is the essence of Tyutchev's religion.' 'Love of suffering - love - love of evil, of destruction. Chaos.' All these characteristics are taken from different fragments of the book 'Two Secrets of Russian Poetry'. But all of them say the same: Tyutchev is related to the religion of evil, chaos, inaction, destruction and selfdestruction. There seems to be a lot of truth in this approach, supported by the poems by Tyutchev and derived from them. Still it is not true because it is not the whole truth about Tyutchev. It was not a mere coincidence that the verses on the basis of which we can speak about Tyutchev as a poet of kindness, space, life and active action just dropped beneath Merezhkovsky's radar."[3, pp. 104-105]

Yu.M. Lotman in one of his last articles about Tyutchev's works also mentioned some oppositions inherent to his lyric poetry, though, as well known, the scholar treated the entire Tyutchev's poetic legacy as the integrated whole, "The interpretation of Tyutchev's body of work as a unified text has become well established. This approach, however, should be agreed with another well-known fact: regular occurrences of contradictory solutions to the same problems in Tyutchev's poetic legacy. Thus, for example, while considering the opposition of 'being' and 'non-being', which is fundamental for the entire system, a researcher looks in bewilderment at a passionately expressed thirst for being. And, on the other side, - at an equally powerful urge to 'taste destruction'. The same can be stated regarding other most significant oppositions, including the 'Russia - West' one." [4, p. 86] 
The complicated worldview contradictions were intertwined in Tyutchev's lyric poetry and, maybe, even determined the paradoxical nature of other aspects of his poems, providing them with that degree of originality and uniqueness which constitute the phenomenon of Tyutchev's poetic legacy. For example, L.V. Pumpyansky, in his study of Tyutchev's style, drew attention to the paradoxical combination of its components: "alloy of Schelling with Derzhavin", "a combination of incompatible styles Romanticism and Baroque". [5, p. 15] "His lyric poetry accustoms us to a monumental style in small forms," said Y.N. Tynyanov about the genre originality of Tyutchev's poetry. [6, p. 51] He assumed that Tyutchev, moving away from the ponderous, "monumental" forms of the XVIII century poetry, turned to the latest "literary form of fragment" developed by the German Romantics. Short poems - fragments - were incorporated into a whole, unified text, being at the same time inclined towards restoration of "the great epic tradition of the XVIII century". [7, p. 52]

Tyutchev's poetry concentrates ontological dimensions of metatext of the new European culture, and a person of his poems is withdrawn beyond any sustainable space and is doomed to rootlessness and metaphysical anguish. The fundamental state of Tyutchev's lyric hero is that of a person facing an elusive space, a human at the abyss. The image of the world is not described - it just flickers in the unfathomable depths. In the poetic world of Tyutchev it is realised in the description of colours (mostly gold, azure, green, smoky, etc.) as lights, and the depiction of light as a glimpse, a flash in the unfathomable darkness ("The Alps (Al'py)", 1830; "Just how it happens during summer (Kak letnej inogda poroju...)", 1863; "How beautiful is the sea at night (Kak horosho ty, o more nochnoe...), 1865; "The East is doubtful and silent (Molchit somnitel'no vostok...)", 1865). A person - facing a "sphinx of nature" ("Nature is a Sphinx. And all the more destructive (Priroda - sfinks. I tem ona vernej...)") and encountering its incomprehensible mystery - dies, tempted to fathom the unfathomable. It faces the person as a destructive temptation.

We can speak of an unresolved crisis of the space inherent to the poetic worldview of Tyutchev. In this context most of the semantic load of Tyutchev's poetry was taken over by the literature of the Silver Age. In the space of culture, the world of Tyutchev's poetry with its "glimpses" and "abysses" proved to be close to the poetic cosmos of Russian Symbolism, with its internal tension and anxiety, submission of reason and will to feelings and mood. The literary work 
by practically all Russian Symbolists, both of the "older" and "younger" generations, was influenced by Tyutchev's poetry. Moreover, many of them considered that his influence almost entirely determined the ontology of the Symbolist aesthetics. So, the major load of the semantic meanings developed by Tyutchev was taken over by the $\mathrm{XX}$ century culture anticipated in his poetry.

\section{References}

[1] Dunaev M.M. Pravoslavie i russkaja literatura (Orthodoxy and Russian Literature). Moscow: Hristianskaja literatura, 1996, 320 p.

[2] lbid.

[3] Skatov N.N. Nekrasov: sovremenniki i prodolzhateli. Ocherki. (Nekrasov: Contemporaries and successors. Sketches). Moscow: Sovetskaya Rossiya, 1986, $336 \mathrm{p}$

[4] Lotman Yu.M. Poeticheskiy mir Tjutcheva (The Poetic World of Tyutchev). Tjutchevskij sbornik. Stat'i o zhizni i tvorchestve Fjodora Ivanovicha Tjutcheva (Tyutchev Collection. Articles about F.I. Tyutchev's Life and Literary Works). Tallin, 1990, 458 p.

[5] Pumpyansky L.V. Pojezija F.I. Tjutcheva (Poetry by F.I. Tyutchev). Uranija. Tjutchevskij al'manah (Urania: Tyutchev Almanac). 1803-1928. Leningrad, 1928, $623 \mathrm{p}$.

[6] Tynyanov Yu.N. Pojetika. Istorija literatury. Kino (Poetics. History of Literature. Cinema). Moscow: Kniga, 1977. 327 p.

[7] lbid. 


\title{
INTEGRATION OF PSYCHOLOGICAL AND PHILOSOPHICAL CONCEPTS M. BEKSULTANOVA IN HUMANISTIC FUNCTIONS
}

\author{
R. Tataeva ${ }^{1}$
}

DOI: http://doi.org/10.15350/L_27/03

\section{Abstract}

This paper analyzes the issues devoted to psychological and philosophical concepts of art M. Beksultanova. Are given the fundamentals and concepts of contemplation, possible to expropriate the psychology of art and humanistic aesthetics.

Keywords: artistic creativity, integration, art, psychology, message of interpretation, didactic humanism, psychological and philosophical aspect.

От колоса должно зерно родиться, от человека - свет его добра...

Иван Минтяк

Обозначая доминантные тенденции чеченской митературы XX века, её значение в историческом процессе, учёные предлагают интеграцию монолитных фигур, созданных принятой порубежной периодизацией, способствующей потенциальному приятию художественно-философских концепций мира и человека. Осуществляя предложенные аргументы цельности, необходимо: концентрировать характеристику комплекса "реализмов" опредеценных ужасом тоталитаризма; изобразить имманентную гибкость модернизма (эволюция символизма к акмеизму, формирование футуризма); предоставить беспристрастную картину противоречий и пафос созидания. Подобный концепт ценностей искусства обусловливает гипотезу о типологии творческих индивидуальностей и дифференциацию "таланта и гениальности художественного созерцания" [1, С. 85]. В целом, аксиология трудов писателей Чечни обусловленная мемуарными оттенками, авто-

\footnotetext{
${ }^{1}$ Rovzan Tataeva, Chechen State Pedagogical University, Russia.
} 
биографией, фрагментами хронологии, митературной иконографией и трагической фатальностью бытия, продолжена М. Бексултановым и "товарищами по цеху".

Объединенные эстетическим сознанием и этнографической атмосферой, произведения Бексултанова фундаментальный потенциал интегрирования и амальгамирования границ гетерогенных интерпретаций, соответствующий знаковой системе и эмементам архифакта. Исповедальные мотивы, определяющие рубежное преломление, означены в его сборниках «Мархийн кІайн гІаргІулеш" ("Облаков журавли белые») - 1985г.; "Юха кханна а селхана санна" (ИИ снова завтра, как вчера») - 1988г.; "Наггахь сайн сагатделча" ("Иногда, когда мне грустно"); "Я хьан тухур хьа неІ" ("И кто постучится в твою дверь") - 2004г.; "Сан вешин тІехьийза йоI" ("Девушка моего брата") - 2011г.

Медитативно интегрируя психолого-философские идеи в гуманистической функции, помогающие индивиду адаптироваться в критических условиях сакральным позитивизмом, писатель творит: “... из подиинного созерцания, недоступного по своей энергии чистоте или глубине его современникам" [2, С.274]. Значит, наблюдение допустимо-используемо в психологии искусства, что отмечено в работе "Одинокий художник" И.А ИАьина: "... тонкому и художественно зоркому психологу предстоит обширное и упоительное поле для исследования; и работа его даст бесконечно много и психологии творчества, и эстетике, и художественной критике, и творящим художникам, и воспринимающим обывате-

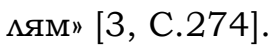

Уникальность Бексултанова, характеризуется медитациями о форме существования, верованиях, нивелированием "биографии души" в периодической фрагментарности, овмадением универсальным методом раскрытия индивидуума, т.е. созданием психологического портрета в интерьере времени, зараженного "пестрой маргинальностью" - основным недугом цивилизаций. Дефиницируя генезис религии и культуру этночеченцев, он соотносит: адаты и Коранические страницы, мифы и трагедии исторической героизации; раскрывает целостную константу социумов во временном пространстве. Направляя сенсуальность Аниме (душе), а не Разуму (рассудку), усилил изображение атомизированных артефактов, губительно вмияющих на будущее.

Данный аспект дидактического гуманизма, научно обосновывают возможности эмансипации и перспективного регресса 
Аичности; синтезируют регулятивную, семиотическую, социальнопсихологическую меру, аргументированную известным хирургом - кибернетиком Н.М. Амосовым в книге "Мысли и сердце». Аналогичная экспозиция бексултановских вопросов и доводов дополнена атомизированными вкраплениями гуманистических граней. Иначе, планомерность тематики, сюжета и композиции повестей, явцяется средством ретроспективного анализа действительности при абсолютном пассеизме автора. В частности, рассказ «Кхуна иза цахиънера" ("Он этого не веда^”) повествует о супружеской паре преклонного возраста, с "мягким консерватизмом». Основанием генерации образов послужиц ценный источник - принцип контраста поколений, достигнутый когнитивным стилем (диалог и монолог), определивший духовное целомудрие стариков.

Созидательная динамика, выраженная фееричными сегментами (фольклор, изысканные обороты речи - шутливая перебранка и воспоминания о прошлом героев), отражают менталитет и субъективное видение этнотрадиции повествователя. Вопреки устойчивому представлению о гармонии поколений в традицион-

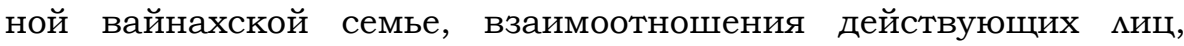
определяется внутренней напряженностью, перешедшей в откровенную апемляцию. Родителей тяготит дегенерация внутрисемейного этикета, аморальная бестактность детей, безвестность:

- Къарибат, алахь... ала мегар дацар-те...

- Оьзда ма дац иза, ва Атаби, муха эр ду ас, йоІан-йоI хима а там болчу... [4, С.336].

- Цхана кхечуьнга...

- Нахе хума муха олу..." [5, С. 337].

- Къарибат, ответь... Может сказать...

- Это же неприлично, ну, Атаби, как, как я скажу подобное..., почти ровеснице внучки....

- А через кого-то...

- Как можно через посторонних....

Кумьминация конфликта возникает с возмущения и антипатичного удивления свекра поведением невестки и сына. Трагическая уникальность ситуации заключается в ожидании стариков внимания со стороны детей через внука. Несоизмеримость страданий родителей усимено мишением их мечты - внука. Прежде всего, это "эффект обманутого ожидания", ввергнувший героев в апогей: "...Воккха стаг букь кагбелча санна, висира... Ц1е уьдура пхенашкхула. Б1аьрса дайра...” [6, С.340]. ("...Старика парализо- 
вало, словно перелом спины... Жар бегал по венам. Свет в очах потух").

Сюжетно, писатемь поражает, потрясающей пустотой в семье, что охватывает страх спровоцированный вечным конфликтом поколений. Х.Ортега-и-Гассет подчеркивац, что “... главное в жизни поколений отнюдь не то, что они сменяют друг друга, гмавное - их взаимопересечение, перехлест" [7, С.274].

Художник не рисует картин борьбы, она на психологическом уровне, в ремарках родителей - Атаби, Къарибат, а также в эпизодически-сепаратном существовании детей, пренебрегших в угоду эфемерностям бытия мировоззренческой схемой и нравственностью, что непостижимо старшим поколением: "...Цунна цахаьара, хІара х1ун ду, х1унда ду, хІара мичара ду, маца ду. Цунна зуда, бераш а деш, керт а мелош, шен доьзам а, цІийнада а 1алашвеш, яха еза моьттинера. Моьттинера боьрша стаг доьзална напагІа а мохуш. уьш шийла а, меца а ца буьтуш. уьш оьзда, гІилмакхехь кхиа а беш, ваха веза. Кхунна моьтург кхуьнцанний кьандемла химлера, тишдемла дІадаьмла. Кхунна иза ца хиънера" [8, С.340]. ("...Он не знал, что это, почему, откуда это, с каких пор. Он думал, что предназначение женщины - это быть заботмивой женой и матерью, хорошей хозяйкой. Думал, что мужчина обязан обеспечить семью. Оберегая семью от голода, холода, обязан воспитать их приличными и порядочными мюдьми. Его мнение с ним же и состарияось, обветшало, исчезцо. Но он этого не знал. Не ведам ...").

Проблемы иццюзорного восприятия молодым поколением мира, требующего жертв, перекликаются с басней И. Крымова "Оракум":

В каком-то капище быц деревянный бог,

И стал он говорить пророчески ответы

И мудрые давать советы.

За то, от головы до ног

Обвешан и серебром и зматом,

Стоял в наряде пребогатом,

Завален жертвами, момьбами заглушен

И фимиамом задушен...

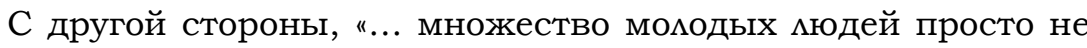
представляют, как можно строить планы на будущее, думать о завтрашнем дне... Дия них все в значительной мере мимолетно, преходяще, поверхностно" [9, С. 54]. 
Сторонник исторически сложившихся патриархальных позиций о семье М. Бексултанов остро переживает трагедию героев: отчужденное одиночество стариков, рецессию преемственности, гипертрофический нигилизм, неопытной молодежи. Это тревога за самоуничижительное поколение, утопающее в пороках, а главное гибнущую породу нации.... Он заинтересован в этнологической адаптации читателя в обозначенной концептуальности, оставшейся дмя читателя туманной.... Проблема преемственности поколений в творчестве автора перманентна, что обусловлено, рокировкой их имманентности и трансцендентности.

Рассказ М. Бексултанова "Кхуна иза цахиънера" ("Он этого не ведал") это месседж современника - современнику о распиате: "... конфликт поколений - универсальный мотив истории. Он базируется на изначальных чертах человеческой натуры... Эта борьба продолжается непрерывно, то скрыто, то явно; она никогда не кончается явным триумфом молодых, ибо к тому времени, когда они побеждали, они уже становились мюдьми средних мет" [10, P. 32].

В целом "краеугольная философия" и неиссякаемая эстетическая концепция Бексултанова, воплощенные в художественных образах произведений обусловлены - динамичностью гуманистических тенденций и антропоцентризмом. Именно гуманистические традиции в творчестве писателя позволяют иначе взглянуть на морально-нравственные аспекты современников, смысл их бытования.... Проблема обретения смысла в условиях кризиса ценностей и авторитетов - одна из социальных проблем, содержащая в себе вызов гуманистической психологии.

\section{References}

[1] Агапов Д.А. Психолого-культурологическая концепция созерцания в работах И.А. ИАьина. Научный журнал "Известия Самарского научного центра РАН" 2009. том 11, № 4. С. 85.

[2] ИАьин И.А. Одинокий художник...: ИАьин И.А. Одинокий художник. Статьи, речи, комментарии. М., Искусство, 1993. С. 273-274.

[3] Там же. С. 274

[4] Бексултанов Муса. Гулйина проза.1-ра том. Я хьн тухур буьйсанна хьан неl... Дийцарш. Соьмжа-гlasа, "ДОШ" издательство, 2005 шо. 736c. C. 336.

[5] Там же C. 337.

[6] Там же С.340.

[7] Ортега-и-Гассет Х. Вокруг Галимея // Он же. Избранные труды. М., 1997. C. 274

[8] Бексултанов Муса. Гулйина проза.1-ра том. Я хьн тухур буьйсанна 
хьан неl... Дийцарш. Соьмжа-гla八а, “ДОШ” издательство, 2005 шо. 736c. С. 336. С.340.

[9] Бобылев С.Н. "Доклад о развитии человеческого потенциала в Российской федерации 2009" М.: Весь мир, 2010. С. 54.

[10] Feuer L.S. The Conflict of Generations. The Character and Significance of Student Movement. NY, 1969. P. 527-528. 14.Ibid. P. 32. 


\title{
COMPARISON AS MEANS OF EVALUATION \\ IN BANNER ADVERTISING
}

\author{
T. Krutko ${ }^{1}$
}

DOI: http://doi.org/10.15350/L_27/04

\begin{abstract}
Comparison is one of the effective means of evaluation in virtual advertising. It is proved that comparative constructions are widely used in the English, Russian, and Ukrainian banner ads. Clausal comparisons as well as combination of superlative and comparative degree can be found in the English banner ads. Phrasal comparisons with a null comparative are typical for the Russian and Ukrainian banner ads.
\end{abstract}

Keywords: banner ads, comparison, advertising discourse.

В рекламном дискурсе оценка является имманентной величиной, адекватную реализацию которой обеспечивают разцичные языковые средства. Ученые насчитывают около десяти показатецей оценности, среди которых мексико-семантические, грамматические, словообразовательные, стилистические и т.д. [2]. Категория оценки, реализованная различными языковыми средствами, является семантическим ядром рекламных текстов, в том числе текстов виртуальной рекламы.

Виртуальная реклама как динамично развивающийся и перспективный тип рекламной коммуникации, характеризующийся визуальными, структурными, содержательными особенностями, уже почти десятиметие привлекает внимание мингвистов. Осуществляется мингвосемиотический анализ текстов баннерной рекламы (Т.В. Крутько), изучаются их когнитивнопрагматические особенности (Е.С. Иванова), коммуникативные стратегии (А.Д. Белова).

Небольшая площадь рекламного баннера и короткое время его воздействия на адресата заставцяют адресанта создавать

${ }^{1}$ Tetiana Krutko, Candidate of Philological Sciences, Associate Professor, National University of Water and Environmental Engineering, Ukraine. 
многоуровневый рекламный текст, в котором простые для когнитивной обработки элементы разных уровней языка, в сочетании с невербальными компонентами, призваны убедить адресата рекмамы в необходимости осуществ ения запрограммированных рекламистами действий, а именно в необходимости активизации баннера [1, с. 184].

Kaк явмение многогранное и постоянно развивающееся

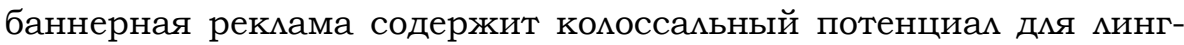
вистических исследований, в частности изучения грамматических способов выражения оценки на материале английского, русского, украинского языков.

В текстах баннерной рекламы грамматические способы выражения оценки, в частности компаративные конструкции, которые активизируют механизм сравнения, явцяются средством формирования и интенсификации воздействующего потенциала рекламного текста.

Функцией компаратива как непосредственного выразителя категории компаративности является обозначение относительной разницы между сравниваемыми предметами или рядами предметов (имплицированными ими эксплицированными) в соответствии со степенью обладания присущим им качеством: Sometimes BIGGER is BETTER; Кавова гуша ерективніша за дорогу космети$\kappa y$.

Используя компаративы, создатели рекламы актуализируют значимые признаки предмета рекламирования, которые домжны отмичать его от других объектов того же вида: Introducing Super Pixel Fonts! Now smoother and cleaner, sell your stuff faster on Yahoo! Classifieds; Nisan Tiida docmynнiше на 4750 у.е.; Копни глубже www.ukrrudprom.com

Текстам баннерной рекламы, относящимся к текстам малой формы, свойственны чрезмерная маконичность, емкость, содержательность текстового наполнения, компрессия. Среди синтаксических форм, характеризующихся этими качествами, особое место занимают неполные сравнительные конструкции с имплицитным эталоном сравнения, которые широко используются в текстах англо-, русско-, украиноязычной рекламы. Атрибутивные компаративы в неполных сравнительных конструкциях помогают подчеркнуть преимущества предмета рекламирования: Now there's an easier faster more accurate way to analyze Web site traffic; Want a better way to search Austin and the web? Click here; Бydb 
выше! VIP объявление; Vепи Більш комфортне гоління.

Среди сравнительных конструкций с эксплицитным эталоном сравнения в англоязычных рекламных текстах фиксируются единицы, где первая часть является предикативной, а вторая непредикативной: He makes more money than you. He gets better jobs than you. He earns more respect than you. He is more in demand than you. You can't beat him unless you join him. Click here for FREE certification tests. Brainbech the measure of achievement; конструкции с двумя непредикативными частями: Visa Smarter than your average card.

Анализ ангмоязычного эмпирического корпуса свидетельствует об обращении копирайтеров к компаративным конструкциям с маркерами сравнения like: Your interest rate shouldn't be like a BLIND DATE; as: Web Authoring Software that is easy as pie; It's easy as 123; Easy as DELL; than: Faster than a speeding bullet. Smarter than a locomotive.

В рекламных текстах, адресованных русскоязычной и украиноязычной аудитории, использование полных сравнительных конструкций с эксплицитным эталоном сравнения является не столь распространенным, как в англоязычной рекламе: Волосы как шелк. Новинка Gliss Kur "Жидкий шелк".

С целью выражения наивысшей оценки в текстах баннерной рекламы копирайтеры используют суперлатив как одно из популярнейших средств объективации максимальной степени проявцения признака: the web's most popular shoe store!; Japan's most explosive director has you in his sights; Expose your listing to the Internet's largest audience; Самый семейный сайm www.7ya.ru; Самая крупная конферениия в Уанете; Найкраші протизламні двері виготовляють в Рівному www.stal-m.иа; board.club.co.ua безкоштовна дошка оголошень: найшвидший спосіб продати, купити, обміняти; Сота Экономь время выбери лучшее!; Самая спортивная новость Чемпионат.ру.

В текстах англоязычной рекламы фиксируется сочетание суперлатива и компаратива, что позволяет рекламистам достигать максимальной интенсификации выражения оценки в рекламном сообщении: Earth's biggest selection just got bigger; The coolest version of Photoshop just got cooler.

В рекламном тексте Low 3.9\% Intro APR Lower 2.9\% Intro APR Lowest O\% Intro APR. Yahoo!Platinum Visa Card дмя демонстрации преимуществ кредитной карточки Visa копирайтеры использова- 
ми компаративно-суперлативную конструкцию в сочетании с синтаксическим параллелизмом, что способствует прогнозируемости рекцамного текста и, соответственно, облегчает его восприятие и запоминаемость.

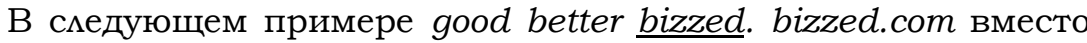
прогнозируемого прилагательного в превосходной степени сравнения best использован адрес рекламируемого веб-сайта. Такой прием позволяет копирайтерам создать эффект обманутого ожидания, когда в высказывании появляется элемент малой вероятности, нарушающий непрерывность сообщения и создающий неожиданность, которые вызывают сопротивцение восприятия, требуют усимия со стороны читателя, а потому симьнее на него воздействуют (И. В. Арнольд). Эффект обманутого ожидания позволяет акцентировать внимание на наиболее значимых компонентах рекцамного сообщения, в данном случае - на адресе вебсайта.

Использование образного сравнения - стилистического приема, основанного на сопоставцении - явцяется средством эмоциональной интенсификации рекламного сообщения: Paradise Falls may look like heaven...; Your faith is like a muscle.

Категория оценки, реализованная при помощи грамматической категории сравнения, выступает средством формирования и интенсификации воздействующего потенциала рекламного текста. Как средство эмоционально-оценочного влияния сравнительные конструкции позволяют рекламистам формировать положительный образ рекламируемого объекта, подчеркивать его исключительность.

Сравнительные конструкции являются прессупозициональным компоненом рекламного текста, то есть вводят информацию, претендующую на статус не требующего доказательств объективного факта, и, соответственно, являются приемом языкового манипулирования. Так, в рекламных текстах Самый удобный сайт объявлений Obyava.ua.net; the web's most popular shoe store! сравнительные конструкции используются с целью усиления директивной имлокуции, убеждения адресата в уникамьности рекламируемых объектов, являются рекомендацией к посещению сайтов и, кроме того, способствуют маконизации рекламных текстов.

Таким образом, сравнительные конструкции, широко используемые в текстах англоязычной, русскоязычной и украиноязычной баннерной рекламы, явцяются средством реализации 
прагматической установки рекламного текста, а именно формирования положительной оценки объекта рекламирования. Среди англоязычных рекламных текстов фиксируются как полные сравнительные конструкции с эксплицитным эталоном сравнения, так и неполные конструкции с имплицитным эталоном сравнения. Для текстов баннерной рекламы на русском и украинском языках характерно использование неполных сравнительных конструкций с имплицитным эталоном сравнения.

References:

[1] Крутько Т.В. Эргономические характеристики виртуальной рекмамы / Т.В. Крутько // Язык - когниция - социум: тезисы докл. Междунар. науч. конф., Минск, 12-13 ноября 2012 г. / редкол.: З.А. Харитончик (отв. ред.) [и др.]. Минск: МГАУ, 2012. С. 183-184.

[2] Кавров Н.И. Факультативные элементы фразеологического значения диалектных ФЕ / Н.И. Аавров / / Актуальные проблемы русской фразеологии. А., 1983. С. 108-112. 
ON THE PROBLEM OF LITERARY TRANSLATION

IN KARAKALPAK LITERARY

\section{T. Bayniyazova ${ }^{1}$}

\section{Abstract}

As is known, in the 20-30 years of the twentieth century, there is the emergence and formation of the Karakalpak literature on the basis of national folklore and classical poetry of XVII-XIX centuries, as well as the poetic experience of fraternal literatures. In this period there is convergence of the Karakalpak literature and art of the peoples of foreign language of artistic expression.

Keywords: translation, literature, translation problems.

Как известно, в 20-30-х годах XX века набцюдается зарождение и формирование каракалпакской $и$ иературы на основе национального фольклора и классической поэзии XVII-XIX веков, а также поэтического опыта братских митератур. В этот период

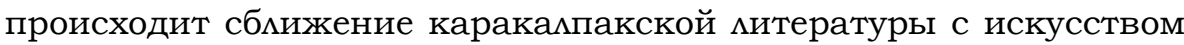
художественного слова иноязычных народов.

Каракалпакский писатель, в дамьнейшем - видный представитель национальной фольклористики К.Аимбетов одним из первых выдвигает идею о творческом обучении у других народов: "русская митература - богатая митература, пользование ею - задача молодых писателей" [1]. В постижении мастерства реалистического отображения действительности каракалпакские писатели, наряду с ознакомлением с художественным творением на языке оригинала, придавали особое значение переводам. Некоторые писатели, помимо создания разнообразных по жанровой форме художественных произведений, занимались ещё и переводческой практикой.

Таким образом, переводы образцов митератур братских народов имели дмя отечественных писателей прежде всего практическое значение, тогда как каракалпакские читатели получили возможность близко познакомиться с творчеством Навои, Низа-

${ }_{1}^{1}$ Tazagul Bayniyazova, Senior Researcher, Karakalpak Research Institute of Humanities, Republic of Karakalpakstan, Uzbekistan. 
ми, Пушкина, Шевченко, Джамбула и других вемиких писателей и поэтов.

Вместе с тем, не всегда первые опыты художественного перевода были удачными, что связано с особенностями творческого самовыражения каждого писателя - представителя культуры братских народов, своеобразия созданного им произведения, а равно и свойствами родного каракалпакского языка. В связи с этим в митературном процессе появцяются первые статьи, посвященные проблемам художественного перевода. Например, вследствие того, что не были учтены особенности стихосложения Маяковского, при переводе некоторых произведений русского поэта бымо допущено искажение содержания стихотворений. В статье «Несколько слов о переводе произведений Маяковского на каракалпакский язык" М.Нурмухамедов обращает внимание на формалистский подход отечественных поэтов к переводу образцов творчества Маяковского. В частности, М.Нурмухамедов останавливается на ошибках, допущенных Ж.Аймурзаевым в 1930-е годы XX века [3].

Подобной критике подвергнуты и басни Крылова, представменные на каракалпакском языке. Н.Урумбаев в статье "Басни Крылова на каракалпакском языке" пишет о том, что Ж.Аймурзаев и Р Мажитов, не вникая в идейное содержание оригинала, самовольно "исправими" его. И русские басни, которым «присущи интонация и ритм разговорной речи, были переданы по традиционному образцу каракалпакской поэзии как четырехстрочный стих. Таким образом, басни Крылова стали песнями, исполняемыми под музыку (т.е. приобрели форму песенных стихов - Т.Б.)" [4].

Статьи А.Жаксыбаева примечательны тем, что в них автор обращается к теоретическим и практическим задачам переводческой деятельности. В частности, ученый-языковед подчеркивает, что переводческая деятельность соотносима с творческой и переводчик домжен с большой ответственностью подходить к своей работе. Дальнейшие наблюдения А.Жаксыбаева за митературным процессом были обобщены в книге «Проблемы художественного перевода".

Установление тесных связей национальной митературы с иноязычным искусством слова Востока и Запада, неотвратимый процесс дальнейшего усимения митературных взаимосвязей привело в свою очередь к появцению переводов образцов каракал- 
пакской митературы на языке различных народов мира. Данное обстоятельство послужило фактором, способствовавшим появлению ряда научных статей и исследований в данном направлении. В своих трудах, посвященных изучению проблемы китературных взаимосвязей, каракалпакские ученые в качестве одной из форм митературных взаимосвязей обращают особое внимание переводам. В настоящее время в каракалпакском митературоведении по данному направлению можно встретить работы М.Нурмухамедова, И.Сагитова, Н.Жапакова, С.Ахметова, К.Мамбетова, Х.Хамидова, С.Аллаярова, К.Курамбаева, П.А^^амбергеновой, М.Бекбергеновой, А.Хамидовой и других ученых.

Сцедует особо отметить заслугу творческой интемлигенции в данной области. Например, каракалпакские писатели С.Мажитов и К.Ауезов стали зачинателями художественного перевода. Народный поэт Каракалпакстана Т.Жумамуратов, стоял во главе комлектива поэтов, переводивших на родной язык "Маобитскую тетрадь" М.Джалиля, а также написал предисловие к ней. Талантмивый каракалпакский поэт И.Юсупов посвятил ряд статей вопросам теории и практики перевода [5], а также занимался переводческой деятельностью. В его творчестве наблюдаются глубокие связи поэтического мастерства каракалпакского народа и мировой китературы. Бмагодаря Х.Турымбетову, М.Сейтниязову, Ш.Сеитову и другим мастерам слова каракалпакский читатель ознакомился с образцами митератур Востока и Запада, но и получил возможность сравнить их с оригиналом.

Дружественные контакты творческой интемлигенции Каракалпакстана указывают на установцение особых взаимоотношений среди представителей разных народов, основанных на глубоком уважении и почитании. Это можно наблюдать на примере узбекско-каракалпакских митературных связей, имеющих далекие исторические корни. Общность происхождения, территориальная близость, сходство культуры способствовала проявлению своеобразных восточных традицийкоторую можно наблюдать и в митературной среде. Например, благодаря народному поэту Узбекистана Миртемиру узбекские читатели получили возможность прочитать произведения Бердаха на родном языке. Работа с материалом каракалпакской митературы, знакомство с традициями классиков каракалпакской митературы - Ажинияза и Бердаха привело к созданию Миртемиром ряда оригинальных творений - 
поэм "На тое Айсанем" (1938), "Воспоминания баксы" (1939), “У берегов Аму" (1946), "День завтрашний" (1947), а затем цикла "Каракампакская тетрадь" (1956-1957).

Восточные традиции наставничества и ученичества ярко проявляются в творчестве известного писателя, академика Г.Гуляма. В сфере науки Г.Гулям занимался исследованием некоторых вопросов каракалпакской митературы. В творческой деятельности Г.Гулям глубоко почитал классиков каракалпакской митературы Ажинияза и Бердаха, считал своим наставником народного поэта Каракалпакстана А.Дабылова. В свою очередь, каракалпакский поэт, писатель и драматург Ж.Аймурзаев в качестве своего учителя и наставника относился с особым уважением к Г.Гуляму [2:51].

Таким образом, узбекско-каракалпакские митературные связи способствовали творческому росту писателей и обогащению искусства художественного слова каждого из этих народов.

Исходя из вышесказанного, можно утверждать, что художественные переводы послужили своеобразной школой мастерства как для самих переводчиков, так и дмя последующего поколения писателей и поэтов. В свою очередь, кучшие произведения каракалпакских писателей к настоящему времени представцены на узбекском, казахском, татарском, русском, корейском, французском и других языках народов мира.

Как мы видим, художественные переводы способствовали проявлению творческого потенциала самого писателя. Интенсивное развитие и глобальная интеграция человечества способствуют неизбежному усимению митературных взаимосвязей, при этом как и для других митератур народов мира, каракалпакской митературе предстоит развиваться и дальше, сохраняя свое национальное своеобразие, целостность и ценность.

В рассмотрении проблемы художественного перевода можно отметить следующие особенности. На начальном этапе зарождения, формирования и развития каракалпакской митературы переводы произведений представителей митератур других народов производимись с практической целью, т.е. имели характер ознакомления с образцами иноязычного поэтического опыта, приобщения к искусству мастерства смова, приобретения навыков в создании разнообразных по своей жанровой форме произведений. При этом можно сказать, что писатели к материалу иноязычных Аитератур подходили с точки зрения прагматики. 
В последующем назревает необходимость творческого подхода к переводческой деятельности, что связано с состоянием развития каракалпакской митературы, накопившей к тому времени определенный опыт и знания в области реалистичного отображения событий и явлений действительности, так и формированием, и развитием национальной филологической науки. В отечественной науке к проблеме художественного перевода обращаются китературоведы, а также ученые-языковеды, поэты и писатели.

Дальнейшая разработка проблем теории художественного перевода явмяется одной из актуальных задач современной каракалпакской митературоведческой науки в связи с необходимостью обобщения полученного ею опыта в области художественного перевода и внедрения в научный оборот накопценного материasa.

References:

[1] Айымбетов Қ. Әдебият мәселеси менен қарақалпақ жас жазыушшыларының уазыйпалары. Мийнеткеш қарақалпақ, № 551930.

[2] Курамбаев К. Адабий тасирдан ижодий ўзига хосликка. Нукус: Қорақалпоғистон, 2007. 60 с.

[3] Нурмухамедов М. Маяковский шығармаларын қарақалпақ тилине ауддарыў туурралы бир-еки сөз. Жас менинши. 16 июль 1953.

[4] Урумбаев Н. Басни Крылова на каракалпакском языке. Советская Каракалпакия, № 1761954.

[5] Юсупов И. Классик поэзияны ауддарыўға кеўил бөлинсин. Совет Қарақалпақстаны, № 125 1957; Мақтымкулының шығармамарын аўдарыўдағы айырым алағатмықмар хақкында. Әмиўдәрья, №10 1983. 


\title{
ADVANTAGES OF USE OF INFORMATION TECHNOLOGIES IN THE STUDY OF FOREIGN LANGUAGE
}

\author{
M. Hurramova ${ }^{1}$
}

\begin{abstract}
The article reveals the benefits of using information technology in the process of learning a foreign language, how is implemented student-centered approach to learning using the World Wide Web, what are the main forms of information technology used at the present stage.
\end{abstract}

Keywords: personality - oriented approach, information and communication technology, cognitive interest.

В условиях информационного общества знания и квалификация приобретают первоочередное значение в жизни человека. Чтобы быть в курсе развития мировой науки, необходимо изучение первоисточников на языке авторов. Поэтому, повышение значимости иностранного языка, его востребованность, оказали влияние на содержание, задачи и динамику обучения.

Современные методики такие, как обучение в сотрудничестве, проектная методика с использованием новых информационных технологий и Интернет-ресурсов помогают реализовать мичностно-ориентированный подход в обучении, обеспечивают индивидуализацию и дифференциацию обучения с учётом способностей студентов, их уровня обученности, склонностей и т.д. [3].

Глобальная сеть Интернет создаёт условия дия получения мюбой необходимой студентам и преподавателям информации, находящейся в Аюбой точке земного шара: страноведческий материал, новости из жизни молодёжи, статьи из газет и журналов, необходимую Аитературу и т.д. Студенты могут принимать участие в викторинах, конкурсах, олимпиадах, проводимых по сети Интернет, переписываться со сверстниками из других стран, участвовать в чатах, видеоконференциях и т.д. Студенты могут

\footnotetext{
${ }^{1}$ Muhayo Hurramova, Department of Foreign Languages, Tashkent Financial Institute, Uzbekistan.
} 
получать информацию по проблеме, над которой работают в данный момент в рамках проекта [2]. Обучение с использованием ресурсов Интернет можно смело отнести к новым педагогическим технологиям. Меняется позиция преподавателя - он перестает быть единственным источником знаний, а становится организатором процесса поиска, переработки информации (возможно, ее адаптации к уровню владения языком обучаемых той или иной группы) и координатором исследования и создания творческих работ школьников и студентов.

Поскольку сегодня требуется свободный доступ к необходимой информации, то в информационных центрах создаются все возможности выхода в научные, культурные и информационные центры всего мира с тем, чтобы в рамках всестороннего изучения той или иной проблемы формировать собственное независимое мнение. Таким образом, студентам домжны быть созданы благоприятные условия дмя использования технологических возможностей современных средств связи как дия поиска и получения информации, так и дмя развития познавательных и коммуникативных способностей и формирования у них умения оперативно принимать решения в сложных ситуациях. Данный процесс наиболее успешно протекает с помощью использования информационных и коммуникационных технологий обучения, включающих специфические способы и технические средства (компьютеры, аудио- и видеосредства, телекоммуникационные сети и т.д.) для работы с информацией.

ДАя студентов мультимедийные технологии являются способом, при помощи которого они расширяют свои представления об окружающем мире. Использование мультимедийных технологий обеспечивает более полную и точную информацию об изучаемых явлениях и объектах. Это повышает качество обучения, позволяет удовиетворять и развивать познавательные интересы студентов, повышает наглядность обучения, позволяя использовать тяжело доступный материал или тот, который нельзя использовать без компьютера. Работа студентов становится более интенсивной, что позволяет повысить темп изучения учебного материала и увеличить объем самостоятельной работы на занятиях и после них. Формы работы с компьютерными обучающими программами на уроках иностранного языка включают: изучение мексики; отработку произношения; обучение диалогической и монологической речи; обучение письму; отработку грамматических явлений. 
Основными формами использования информационных технологий являются следующие:

1) мультимедиауроки, которые проводятся на основе компьютерных обучающих программ;

2) уроки на основе авторских компьютерных презентаций в ходе мекций, семинаров, мабораторных работ, докладов студентов. Так, с помощью компьютерной программы PowerPoint преподаватели организуют серии мультимедийных уроков, учебных модумей, эмектронных учебных пособий, которые позволяют интегрировать аудиовизуальную информацию, представленную в размичной форме - графика, слайды, текст, видеофильм и т.д.;

3) тестирование на компьютерах;

Отсюда информационные ресурсы сети Интернет органично интегрируются в учебный процесс, помогая решать размичные дидактические задачи на занятиях по иностранному языку, например, такие, как:

- формирование навыков чтения;

- пополнение своего словарного запаса изучаемого языка;

- совершенствование умения письменной речи, например, при составлении ответов своим партнерам по общению;

- совершенствование аудирования на основе оригинальных звуковых текстов сети Интернет;

- знакомство с культурой, речевым этикетом, особенностями речевого поведения страны изучаемого языка;

- совершенствование умения монологического и диалогического высказывания;

- формирование мотивации к иноязычной речевой деятельности и знанию специфики академического письма.

Преимущества применения информационных технологий по сравнению с традиционными методами выражаются в сочетании аудио- и видеонаглядности, возможности использования интерактивной доски, обеспечении эффективности восприятия и запоминания учебного материала, экономии учебного времени.

Говоря о технологии, имеют в виду систему действий, приводящую к ожидаемому результату. В системе преподавания иностранных языков уже давно созданы методики, претендующие на статус технологии, т.е. обладающие высокой степенью надёжности, стабильности и воспроизводимости результатов. Мы относим сюда прежде всего Аичностно-ориентированный подход при обучении иностранному языку, включающий метод проектов, обуче- 
ние в сотрудничестве, ролевые игры, контекстное обучение, интенсивное обучение и разноуровневое обучение.

Конечно, не следует забывать, что учат учителя, а не компьютеры. Компьютер - всего мишь сложная машина на службе у человека, и она никогда не заменит учителя. Однако приведем замечание Бимла Гейтса "Все компьютеры в мире ничего не изменят без наличия увлеченных учащихся, знающих и преданных своему делу преподавателей, неравнодушных и осведомленных родителей, а также общества, в котором подчеркивается ценность обучения на протяжении всей жизни". Целью обучения при современном коммуникативном подходе к преподаванию языков явцяется, прежде всего, развитие способности иноязычного общения как особой социальной формы межкультурного взаимодействия, воспроизведение которой в полном объеме в рамках чемовеко-машинного взаимодействия в настоящее время кажется маловероятным.

Выделяя преимущества использования Интернет-ресурсов перед традиционными методами обучения, необходимо исходить из противоречий урока, обусловценных недостатками традиционного обучения:

•комлективное обучение - индивидуальное обучение;

•регулярность прямой связи - нерегулярность обратной связи;

•большой объем информации - временные рамки урока [1].

Таким образом, применение Интернет-технологий при обучении иностранному языку студентов вуза позволяет значительно расширить рамки учебного процесса, сделать его более интересным, эффективным и оптимальным.

References:

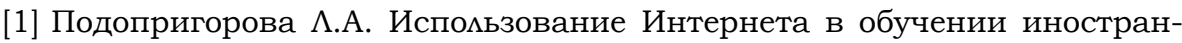
ным языкам // Иностранные языки в школе. 2003. № 5. С. 25-31.

[2] Туркина Н.В. Работа над проектом при обучении английскому языку // Иностранные языки в школе. 2002. № 3. С. 46.

[3] Якиманская И.С. Аичностно ориентированное обучение в современной школе. М.: Сентябрь, 1996. С. 115. 


\section{FEATURES OF THE FOREIGN LANGUAGE TEACHING NOT LANGUAGE HIGH SCHOOL}

\section{Bozorova ${ }^{1}$}

\section{Abstract}

The article reveals the peculiarities of the organization of foreign language teaching, careful approach to the selection of educational material in the process of learning a foreign language, which active teaching methods are used at the present stage, as detailed thought and methodically well-organized role playing promotes active involvement of students in the learning process.

Keywords: foreign language competence, lexical and grammatical minimum, the goal-setting process, problem-based learning.

На современном этапе развития общества потребность в быстром и эффективном в овладении иностранным языком вызвала к жизни новые формы и методы обучения, дала толчок к развитию так называемых "активных методов".

Активные методы обучения иностранным языкам основаны на принципе непосредственного участия, который обязывает преподавателя сделать каждого студента активным участником учебно-воспитательного процесса, ведущим поиск путей и способов решения обсуждаемой проблемы. Используя активный метод в обучении иностранным языкам, преподаватель сотрудничает с учащимся, относится к нему как к полноправному объекту. Между преподавателем и обучаемым присутствуют субъектсубъектные отношения. преподаватель-руководитель и организатор межличностных отношений, при этом он выступает в роли эксперта. снабжая обучающихся недостающей информацией и средствами оформления мысли [1].

Активные методы обучения обладают следующими особенностями:

\footnotetext{
${ }^{1}$ Mubarak Bozorova, Senior Lecturer of English, Department of Foreign Languages, Tashkent Financial Institute, Uzbekistan.
} 
- высшая степень сознательности в активизации мышления, восприятия и поведения обучающихся;

- высокая степень вовлеченности в процесс обучения и обязательность взаимодействия обучающихся между собой;

- высокий уровень мотивации и творчества в обучении;

- эффективность развития профессионально-прикладных навыков и умений в сжатые сроки.

Одной из стратегических целей современного образования явцяется превращение студента в активный субъект собственного учения. Он должен быть психологически и функционально готов в зависимости от своих способностей, интересов, наклонностей и жизненных планов - выстраивать индивидуальную образовательную траекторию, вести исследовательский поиск, извлекать из различных источников информацию и превращать ее в знание. Дия этого необходимо, чтобы студент: - занимал в обучении активную позицию; - мог мобилизовать интелмектуальные и волевые усилия дия достижения учебных целей; - умем прогнозировать, проектировать и планировать учебную деятельность; - был способен инициировать свою познавательную деятельность на основе внутренней мотивации.

Положительное влияние иноязычных компетенций у студентов, в отличие от школьников, например, заключается в том, что взрослые учащиеся, как правицо, серьезнее относятся к учению. Они осознают, что им придется сталкиваться с иностранными языками на практике, например, в процессе работы при чтении и составцении иноязычных документов, во время путешествий, при общении с зарубежными партнерами.

Взрослый учащийся, как указано выше, обладает способностью к волевому усицию, и это качество помогает ему преодолевать трудности, а процесс обучения иностранным языкам по своей сути трудоемкий, занимающий значительный период времени [2]. Работа преподавателя вуза, в отличие от школьного учителя, частично облегчается более развитым мышлением взрослых обучающихся, способностью сопоставцять и осмысливать, в том чисме языковые явмения.

Однако, особенности организации обучения иностранному языку в вузе нефилологического профиля, зачастую, сводят к "нумю" усилия преподавателей и студентов [3]. Преподавателю необходимо в условиях такого вуза особенно настойчиво искать пути 
упцотнения при прохождении материала, способы отбора необходимого и достаточного мексико-грамматического минимума, aктивизации деятельности всех студентов. Необходим более тщательный подход к отбору учебного материала и методов преподавания в неязыковом вузе, учет возрастных особенностей обучающихся, то есть тех требований, которые студент, будучи взрослым человеком, объективно предъявляет к учебному процессу.

В частности, при управцении учебным процессом, постоянно вкАючать студентов в процесс целеполагания в работе должно стать правилом, так как студенту необходимо четко представлять перспективы не только к концу изучения иностранного языка в вузе, но и на каждом отдельном этапе процесса обучения [2]. То есть, принимая во внимание при обучении добровольный характер работы взрослого учащегося, конкретность, безотмагательность задач, которые он ставит перед собой, необходимо постоянно знакомить студентов с учебным планом.

Индивидуальный учебный план выполняет в системе высшего образования следующие функции:

- компенсационная (компенсация запаздывающей учебной динамики обучающегося),

- оптимизационная (обеспечение оптимальных условий дмя обучающихся, обладающих индивидуальными интелмектуальнопсихологическими особенностями),

- адаптационная (адаптация обучающихся, не способных в силу объективных причин освоить тот или иной курс),

- функция интенсификации (обеспечение более высокого темпа усвоения того или иного курса),

- функция расширения содержания образования (введение в содержание углубленных курсов),

- функция обеспечения учебной мобильности (за счет привцечения сетевых кадровых ресурсов),

- здоровьесберегающая (уменьшение непродуктивной нагрузки на обучающегося) [4].

Игровые технологии [1] формируют такие ключевые компетенции, которыми должен обладать каждый чмен общества, (общение, умение работать с другими, умение учиться и совершенствоваться), а также обобщенные предметные умения (умение решать те конкретные задачи, которые будут возникать в жизни, например, понимание иноязычной речи). 
Основными этапами обучающей ролевой игры явцяются: выдвижение и обсуждение идеи относительно коммуникативной ситуации (обязательным элементом ролевой игры является разрешение проблемной ситуации), набора ролей и примерного хода и правил предстоящей игры; распределение ролей и определение содержания (сценария) ролевой игры; подготовка комплекта игровой документации (опознавательные знаки, эмблемы, плакаты); индивидуальная подготовка каждого обучающегося к предстоящей игре; проведение ролевой игры; подведение итогов.

Традиционно применяемые в вузовской практике формы организации обучения с их упрочившейся структурой не могут в полной мере удовлетворить потребности обучающихся в новых знаниях, в разносторонних познавательных интересах; обеспечить формирование творческой мичности, реализацию духовных и профессиональных потребностей.

Студенты эффективнее овцадевают способами решения проблемно-ситуативных задач с помощью заданий интерактивного коммуникативного характера, стимулирующих речевое мышмение и взаимодействие участников.

Данные задания используются как средства коммуникативно-ориентированного обучения иностранному языку, например, задания в форме коммуникативных деловых игр и "круглых стомов", имитирующих реальное деловое общение, создающих информационное неравенство между участниками [1].

Качественно новая подготовка выпускников, формирование их творческих способностей и творческого мышления, готовность к рационализаторской и изобретательской деятельности явмяется основным ориентиром и индикатором профессиональной пригодности современных форм обучения.

References:

[1] Запесоцкий А. Какого человека должна сформировать сегодня система образования? // Высшее образование в России. 2003. № 3. С. 4560.

[2] Колесникова И.А., Алтарева С.А. Технологии разработки учебных программ по иностранным языкам // Методика обучения иностранным языкам в средней школе. Пособие дмя учителей, аспирантов и студентов. СПб.: KAPO, 2008. С. 18-30. 
[3] Соловова Е.Н. Методика обучения иностранным языкам: продвинутый курс: пособие дмя студентов пед. вузов и учителей. М..: АСТ: Астрель, 2008. С. 20-36.

[4] Титова, О.А., Головина, И.В. Школьное образование: стандарты и инновации [Текст] // Роль университетов и музеев в проведении гуманитарных научных исскедований: Мат-лы VI Международной научнопрактической конференции. Тума: Изд-во ТГПУ им. А.Н. Толстого, 2011. C. $225-227$. 
COMPETENCE APPROACH STUDY A FOREIGN LANGUAGE IN NOT LANGUAGE HIGH SCHOOL

\author{
N. Muradova1
}

\title{
Abstract
}

In article the issue of competence-based approach of a learning of foreign language, essence of educational technologies of training in a foreign language is touched, questions of use of language as means of communication are considered.

Keywords: competence-based approach, educational cognitive activity, the personal focused approach.

С тех пор как в человеческом обществе возникла необходимость в обучении иностранному языку, появилась и задача поиска эффективных путей достижения этой цели. В наше время эта проблема приняла поистине глобальный характер: вопросами обучения иностранному языку занимаются практически во всех странах мира.

Студенты неязыковых ВУЗов не заинтересованы в изучении иностранных языков и в большинстве случаев ведут себя пассивно на занятиях и при выполнении домашних заданий. В связи с этим преподавателю необходимо создать благоприятные условия усвоения языка, к которым относятся относительно высокая значимость целевых установок и умеренные трудности процесса усвоения. Преподаватель должен убедить студентов в том, что изучение иностранного языка необходимо дмя успешности их профессиональной деятельности в будущем, то есть необходимо сформировать у них потребности в изучении иностранного языка. В данном случае говорят о "личностном смысле" предмета изучения в структуре мотивации. Субъект прогнозирует реальные последствия овладения иностранным языком дмя дальнейшей жизнедеятельности в плане перспектив своего развития. Дия неязыковых ВУЗов характерно сочетание низкого уровня притязаний и потребностей во внешних стимулах со стороны студентов с

\footnotetext{
${ }^{1}$ Nasiba Muradova, Department of Foreign Languages, Tashkent Financial Institute, Uzbekistan.
} 
более высокой регламентации учебных действий со стороны преподавателя.

Разрабатывая содержание обучения, стоит учитывать и то, что содержание каждого учебного предмета является органичной частью содержания образования в целом и поэтому должно способствовать достижению общих образовательных целей (наряду с формированием некоего объема знаний, умений, навыков оно должно обеспечивать возможность развития учебнопознавательных умений у обучаемых, формировать у них способности к самостоятельному мышлению, постоянному обновлению знаний и их обобщению, умения мыслить системно, выходя за узкие рамки содержания конкретного учебного предмета при решении комплексных практических задач).

Современная практика совершенствования иноязычной подготовки обучающихся всех уровней находится в центре внимания психолого-педагогической науки. Исследователи выбирают размичные педагогические подходы к реализации этой цели. Одним из перспективных на современном этапе многие исследователи считают компетентностный подход.

При обучении иностранному языку используются следующие образовательные технологии:

-Технология коммуникативного обучения - направлена на формирование коммуникативной компетентности студентов

-Технология разноуровневого (дифференцированного) обучения - предполагает осуществление познавательной деятельности студентов с учётом их индивидуальных способностей, возможностей и интересов, поощряя их реализовывать свой творческий потенциал.

-Технология модульного обучения - предусматривает демение содержания дисциплины на достаточно автономные разделы (модули), интегрированные в общий курс.

-Информационно-коммуникационные технологии (ИКТ) расширяют рамки образовательного процесса, повышая его практическую направленность, способствуют интенсификации самостоятельной работы студентов и повышению познавательной активности.

-Проектная технология - ориентирована на моделирование социального взаимодействия обучающихся с целью решения задачи, которая определяется в рамках профессиональной подготовки студентов, выделяя ту или иную предметную область. 
Реализация компетентностного подхода с использованием перечисленных технологий предусматривает активные и интерактивные формы обучения, такие как деловые и ролевые игры, разбор конкретных ситуаций, колмективная мыслительная деятельность, дискуссии, работа над проектами научноисследовательского характера и т.д.

Самой естественной и продуктивной формой практики свободного говорения дмя изучающих иностранный язык явцяется групповое обсуждение проблемы в процессе взаимного обмена мнениями, другими словами, дискуссия. Участие в дискуссии вызывает у обучаемых готовность изможить свою позицию в наибомее яркой, убедительной форме, найти такие слова и выражения, такие аргументы, которые бы наиболее полно отражали их нравственную позицию - и все это на иностранном языке. Этим определяется огромная ценность дискуссии в процессе его изучения.

Что касается игры, то в ней, в данном случае, в деловой все стороны равны. По аспекту языка игры делятся на: фонетические, мексические, грамматические, синтаксические, стилистические; по виду речевой деятельности: обучение аудированию, обучение диалогической и монологической речи, обучение чтению, обучение письму; по форме проведения: предметные, подвижные с вербальным компонентом, сюжетные, ролевые, игрысоревнования, интелмектуальные игры, игры взаимодействия; по способу организации: компьютерные, письменные, устные, имитационные, креативные; по сложности и дмительности; по количественному составу участников: индивидуальные, парные, групповые, командные, коцлективные; по целевым ориентациям: дидактические, воспитывающие, развивающие, социализирующие.

Ролевая игра позволяет учитывать возрастные особенности учащихся, их интересы, выступает как эффективное средство создания и развития мотивов к иноязычному диалогическому общению, способствует реализации кичностно-ориентированного подхода в обучении иностранному языку, когда в центре внимания находится обучающийся со своими интересами, эмоциями, переживаниями, потребностями. Моделирование такого рода ситуаций позволяет приблизить речевую деятельность к реальной коммуникации, возможность использования языка как средства общения, актуализируя как вербальные, так и невербальные средства общения. Тем самым ролевая игра обеспечивает реали- 
зацию общего методического принципа коммуникативной направценности обучения иностранному языку.

Такой подход позволяет вовлечь большинство студентов в совместную деятельность по достижению поставленных целей, активизировать речевую активность обучаемых, испытать позитивно-эмоциональное состояние от познавательного общения, осознать необходимость достижения и вступления в познавательное общение, понизить уровень тревожности и снять психологические барьеры при порождении иноязычной речи.

Необходимо понимать, что изучаемый язык - это не просто набор слов и правиц, а пространство со своими оттенками, цветом, запахом, образами. Не следует замыкаться на правилах, а нужно просто говорить и не бояться допустить ошибки. Пусть поначалу их будет много, но основная задача - говорить, а уже после - говорить правицьно. Само изучение языка со всеми его глубинами и красками будет, постоянно тормозится, если вначале разбавить всю его палитру сводом правиц. Не стоит бояться ошибок, пусть в общении правит свобода. Нужно задумываться - что сказать, а не как правильно. Однако известно, что овмадеть иностранным языком - значит научиться мыслить на этом языке.

References:

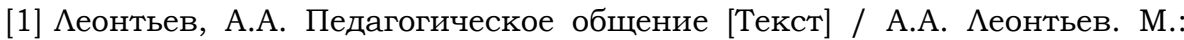
Знание, 1979. 48 с.

[2] Языкова, Н.В. Вопросы подготовки учителя. Цели и содержание методической подготовки студентов пед. факультетов ин. языков [Текст] / Н.В. Языкова // Иностранные языки в школе. 1995. № 3. С. 38. 


\section{PRAGMATIC ASPECT OF TRANSLATION GENRE OF TUYUQ}

\section{Z. Shukurova ${ }^{1}$}

\section{Abstract}

The aim of this article is showing the ways of translation of tuyuqs, one of the shortest form of classical poetry on the basic interpretation Alisher Navoiy's some tuyuqs. Shoving methods recreation rhymes which are formed by usage of homonyms, verifying the merit of loosening cognitive dissonance. On the basis of our interpretation we notify the following thesis: The ST and TT are similar but not the same. The TT is close to the ST in its form semantics are of usage of words, but differ in the usage of rhythm as theris no such poetic rhythm (arooz) in English.

Keywords: rhythm, pragmatic, cognitive, dissonance.

Четверостишие туюг - известный мирический жанр в классических тюрко-язычных митературах, обычно писалось одним из размеров аруза с системой рифм ааба, реже абвб, в исключительных случаях - аааа, с игрой слов в рифме (таджнис). Впервые сведения о туюге как о Аитературном жанре, приведены в трактате по просодии Алишера Навои “Весы размеров" (конец 15 в.). В частности, Алишер Навои отмечает, что тюрки отличается от персидско-таджикского языка обилием многозначных слов в словарном составе, что дает возможность использовать в стихотворчестве таких поэтических приёмов как, таджнис, ийхом, туюг, основанные на игре слов. $[1,179]$

Как тюркская поэтическая форма, туюг охарактеризован также Бабуром в его "Трактате об арузе" (начало 16 в.). По сведениям Бабура, "туюг, образуется постепенным приспособлением древнетюркского народного песенного размера одному из размеров аруза, а именно, "рамали мусаддаси солими мақсур", парадигма которого:

1Zilola Shukurova, Senior Researcher of Samarkand State Institute of Foreign Languages, Uzbekistan. 


$$
\begin{array}{lll}
\text { фоилотун } & \text { фоилотун } & \text { фоилон (или фоилун) } \\
-\mathbf{v}-- & -\mathbf{v}-- & -\mathbf{v}-.
\end{array}
$$

Первый переводчик туюгов Алишера Навои на русский язык начала XX века А.Н.Самойлович охарактеризовал жанр так: форма туюга восходит к устным народным четверостишиям, основанных на намек и цегкую иронию; со временем приобретавшая приём “таджнис" из арабо-персидской митературы ". [3,14]

Следовательно, можно сказать, что именно этот близкий фольклорному слогу размер, и открыл возможности выразить мирические переживания с юмором, основываясь на игре слов, что отмичает жанр от кытъа и рубаи.

Серьезные исследования туюга как митературного жанра начинается со второй половины XIX-го века и продолжается в XX веке. (Ф.Е.Корш, Е.Гибб, П.М.Мемиоранский, А.И.Самойцович, Ф.Купрулузода, Х.Зариф, И.В.Стеблева, Б.Вамиходжаев, Н.Мамлаев, Р.Орзибеков, А.Багиров и др.).

В частности, Р.Орзибеков отмечает, что Навои искуссно использовал все разновидности жанра: тажниси мафрук(раздеменный таджнис), тажниси мулаффак(сочетание компонентов таджниса). Также он излагает выводы о самом распространенном виде жанра: 1) независимое, целостное произведение, состоящее из четырех строк; 2) рифмуется в основном -a,a,б,а иногда -a,a,a,a; 3) композиционный строй как и в рубаи в 1-строке тезис, во 2-второй антитезис, 3-строка -суть туюга и 4-строка синтез; Однако, в отличии от рубаи, пишется предельно одним размером и омонимичные слова в конце строк должны служить раскрытию поэтического смысла. [4,88]

Своеобразие жанра требует особой подготовценности от переводчика. (об этом упоминается в работах Г.Саломова, С.Иванова, Г.Гофуровой.) [5, 115]

Именно поэтому русские переводчики туюгов Навои А.Н.Самойлович и С.Н.Иванов старались интерпретировать свои переводные варианты. А.Н.Самойцович указывает количество туюгов Навои 16 и интерпретирует всех использованных им в переводе омонимичных слов. (В рамках данной статьи не будем останав иваться в подробностях переводов А.Н.Самойцовича.) 
Однако, “Сокровищница мыслей", (последний, четвертый диван) включает 13туюгов, 11 из них переведены С.Н.Ивановым, в размере семистопного ямба, с разбивом после каждого четвертого слога: 15-слоговой (женской рифмой) и 14-слоговой (мужской рифмой), которые вошли во второй том десятитомного издания произведений А^ишер Навои на русском языке(1968г.). Переводчик разработал следующие принципы перевода данного жанра:

- воссоздать форму и содержание туюга в переводе;

- избранные дмя рифмы слова -омонимы могут быть коренными или составными;

- в рифмованных словах сохранить тонький поэтический намек, степень комизма;

- по мере возможности не увеличивать количество слогов в строке (если иметь ввиду среднюю длину слов в русском языке, протянутых по отношению к узбекским, то естественно, количество слогов в строке должно быть больше чем в оригинаме.). [6, 197]

Следовательно, можно сказать, что не овладевая теоретической базой жанра, сложного по форме, невозможно воссоздать прагматический потенциал туюга в переводе.

Однако, в последующие 50 мет переводами туюгов Навои никто не занимался. В годы Независимости Республики Узбекистан, начался некоторый сдвиг и в данной области. Непосредственные переводы мирических жанров А^ишера Навои на английский язык были осуществлены К.Маъмуровым, $\Lambda$. Кметюк, Д.Суцтановой.

В частности, жанр тюркского туюга впервые был переведен на английский язык Д.Султановой. В данной статьи впервые попытаемся рассмотреть вопрос о прагматической ценности переводных репрезентаций на русском и английском языках одного из туюгов Навои и определить степень когнитивного диссонанса между ТО и ТП.

Ниже в таблице приводим ТО, ТП-1 (перевод на русский язык С.Иванова), ТП-2 (перевод на английский язык Д.Султановой): 


\begin{tabular}{|c|c|c|}
\hline $\begin{array}{c}\text { Жавр ўқин жонимға } \\
\text { соқий ёзмади }\end{array}$ & $\begin{array}{c}\text { Стрела обиды в грудь } \\
\text { впимась и сердце мне } \\
\text { задема }\end{array}$ & $\begin{array}{l}\text { O wine server with blows of } \\
\text { mischief me not moved, }\end{array}$ \\
\hline $\begin{array}{c}\text { Васл жомидин } \\
\text { хуморим ёзмади. }\end{array}$ & $\begin{array}{c}\text { Едва утихнувшая страсть } \\
\text { опять взялась за демо. }\end{array}$ & $\begin{array}{l}\text { And my long for beholding } \\
\text { lover wasn't down moved. }\end{array}$ \\
\hline $\begin{array}{c}\text { Кикки кудрат сабз } \\
\text { хатмар ишқидин }\end{array}$ & $\begin{array}{c}\text { Так предначертано } \\
\text { судьбой: мы страстью } \\
\text { рвемся к юным }\end{array}$ & $\begin{array}{c}\text { I wished enjoy the love } \\
\text { soaked with taste of her } \\
\text { lips, }\end{array}$ \\
\hline $\begin{array}{c}\text { Ўзга иш омцимға гўё } \\
\text { ёзмади }\end{array}$ & 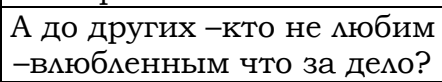 & $\begin{array}{l}\text { But that desire of mine by } \\
\text { my fate made off moved. }\end{array}$ \\
\hline
\end{tabular}

По В.Н.Комиссарову, прагматическое воздействие перевода определяется тремя факторами: 1)содержание высказывания; 2)характер знаков, составляющих высказывание; 3)тип рецептора. [7, 137]

Суммируя научные выводы и переводческий опыт по данному жанру и опираясь на собственные анализы всех 13 туюгов Навои, попытаемся сформулировать общую схему анализа содержания и формы текста, предопределяющих прагматический потенциал перевода:

а) ограниченность тематического поля туюгов;

б) описание мирическим героем внешности, поведения, жестов и т.п. одного из коммуникантов;

в) своеобразие способа повествования. При этом, нужно учитывать национально -ментальные черты, отраженные в жестах, мимике;

г) контекстуальное значение тройной омонимии следует раскрыть по их эмоциональной окрашенности;

е) коммуникативную цель туюга можно определить через интерпретацию омонимов в конце строк.

Итак, обращаем внимание на ТО туюг с редифом “ёзмади”(не отметил):

на основе игры слов мегкий намек на недовольство своей судьбой мирического героя. В функции рифмы -отрицательная форма узбекского глагола “ёзмоқ", использованная в трёх значениях:

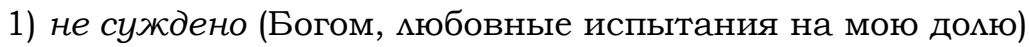

2) не прошло (у меня чувство пристрастия к чаше мюбви).

3) не развернула как будьто (мощь перо предо мной ничего, кроме начертания страсти мюбви к нежным пушкам над губами красавицы). 
Нужно отметить, что одним из продуктивных грамматических приёмов воссоздания фрормы туюга является отрицательная форма глагола. У Навои таких насчитывается 3.

Как отмечает И.В.Арнольд, “отрицательные конструкции более впечатлительны, относительно подтвердитемьных и еще симьнее усимивают волнение". [8, 167]

Таким образом, можно подтвердить, что перевод осуществлен по принципу третьего типа прагматической адаптации, то есть переводчик старался передать не сказанное буквально, а подразумеваемое. При этом сохраняет форму высказывания.

Благозвучие оригинала (эвфония) достигается повтором звонкого согмасного[ж], гмасные звуки [о] и[ё] выражают сожаление, огорчение.

В процессе сопоставительного анализа данного туюга выявцены следующие соответствия / несоответствия переводов с текстом оригинала:

В ТП-1 использован15 слоговый семистопный ямб, в результате чувствуется растянутость ритма. План содержания несколько изменен, выражение недовольства преувеличивается. Однако, степень комизма сохраняется. Переводчик сумел воссоздать форму туюга, использовав в одной строке прошедшее время глагола (задела), во второй и четвертой строках словосочетание “за дело” в двух разных значениях, создавая омографическую рифму.

Жавр $\check{\boldsymbol{y}} \boldsymbol{u}$-стрела обидъ: метафора воссоздаётся

хуморим ёзмади -страсть взялась за дело: метафора “васл

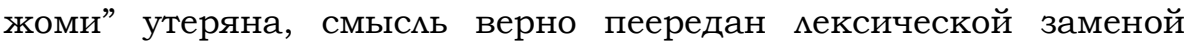
(страсть), при этом воссозданы игра слов и омония;

соқий -судъба: известный поэтический образ восточной мирики (виночерпий) употребляется в прямом смысле;

, уузга ии ёзмади- ито за дело до других: воссоздана русской фразой подразумеваемое в ТО;

, сабз хатлар ииқидин - страстью рвемся $\kappa$ юными: мексическую замену образной метонимии “нежный пушок” со словосочетанием “ $\kappa$ юньим" можно объяснить как ассоциации семы “сабз”, означающей молодая, свежая (трава). Переводчик умышленно пропускает данную метонимию, не характерную для восприятия рецептора переводимого языка. 
В ТП-1 использованы ассонанс [a], [е], амлитерация [c], [3], повтор (задела, за дело), обеспечивающие музыкальность туюга.

ТП-2 количество слогов увеличивается на два, форма туюга воспроизводится, сохранена рифмовка, план содержания приближается к ТО, план выражения идентичен оригиналу. Применены приём амлитерации повтором сонорного звука [L], дмя представления состояния цирического героя используется заднеязычные гмасные звуки[а], [e], дифтонг [ou], что обеспечивает близость духу ТО.

Таким образом, можно подтвердить, что ТП-1 и ТП-2 соответствуют прагматическим нормам перевода:

-в ТП-1 и ТП-2 воспроизведены план содержания и план выражения данного туюга;

-ТП-1 замечается растянутость, а ТП-2 приближается к метру оригинала;

-в ТП-1 и ТП-2 сохранена степень восточного юмора;

-для воссоздания благозвучия оригинала исползованы фонетические средства русского и английского языков;

-в создании омонимичных слов С.Иванов использует различные формы глагола, имени примагательного словосочетания, Д.Суцтанова вместо многозначных слов рифмует фразы, состоящие из одного слова.

Таким образом, прагматический аспект перевода обеспечивает идентичность восприятия рецептором как текста в целом в плане содержания, так и отдельных формальных сторон жанра. И перевод данного интереснейшего жанра требует от переводчика особого внимания, знания языковых тонкостей. В данном случае, прагматичекая ценность ТП-1 и ТП-2 равноценна TO.

References:

[1] Навоий, Алишер, Асарлар, 15 томлик, 14 том. Б.179.

[2] Бобур.Танманган асарлар. ЎзФАН, Тошкент, Б.162.

[3] Самоймович А.Н. Четверостишие туюги Навои.// Мусумьманский мир СПб., 1917. вып.І.-С.10-22.

[4] Орзибеков Р. Ўзбек шеърияти жанрлари.//Ўкув кўмманма -Самарқанд, 1998, 1446.

[5] Саломов Ғ. Таржима назариясига кириш. Т.: Ўқитувчи, 1978. 1156

[6] Иванов С. Туюқнинг куюқ маъноси / Таржима санъати: Мақолалар тўплами. 5-китоб. Т.: Адабиёт ва санъат нашриети, 1980. 
PHILOLOGY, LITERATURES AND LINGUISTICS

[7] Комиссаров В.Н. Современное переводоведение 2-е изд.,испр. М.: Р.Валент, 2011. 408 с.

[8] Арнольд И.В. Стилистика английского языка. М.,1966. 346 с. 


\section{THE SYMBOLIC-ALLEGORICAL SHAPES \\ IN HOMILIES SULKHAN SABA ORBELIANI}

\section{Khandzhalashvili ${ }^{1}$}

\section{Abstract}

The collection of "Sermons" of the great Georgian writer Sulkhan Saba of Orbeliani ranks high in his creativity. The writer uses in the collection methods a symbolical and allegorical method of "Scripture". His allegorizm can be several types, in particular, the facts, bible characters, moralistic and subject which the preacher uses purposefully by means of judgment of persons of Shabby and New Precepts. According to Saba if the phenomenon is connected with the fundamental principle, as the person, then the true phenomenon of the person, won't be able to reach fundamental principles of the person therefore judgment has to happen to the help of persons and icons. The author of article pays attention to a little symbolical and allegorical interpretation and the paradigms listed in the work. Among them paradigms of church, spiritual wisdom, a sin, the Gospel and Noah's Ark are interesting.

Keywords: Sulkhan-Saba Orbeliani, a sermon, an allegory, the "Old Testament", "New Testament" church, heaven, sin, Noah's Ark, a symbol.

Сулхан Саба Орбелиани (1658-1725) в своем сборнике проповедей "Учение" использует "Священное писание" методом символическо-аммегорической интерпретации.

В его "Проповедях" видна тенденция художественного восприятия "Библии"

Его амлегоризмы нескольких видов:

1)А^мегории фактов и событий,

2)А^мегория библейских персонажей,

3)Предметная аммегория,

4)Алмегории морального характера.

${ }^{1}$ Marina Khandzhalashvili, Doctoral, Faculty of Humanities, Iakob Gogebashvili Telavi State University, Georgia. 
Эти четыре вида служат одной цели: осмысление миц и явмений "Ветхого Завета", как пралица и явцения "Нового Завета"

В одной из проповедей Саба пишет:

"\иио Старого закона было лииом Нового закона: также как художник впервые нарисовал тень иконы, а затем исполнил ее в uвeme"

Таким образом, "Ветхий Завет", "Новый Завет", прототипы "образов", или мица-символы.

Саба сравнивает "Ветхий Завет" с контуром, исполненным художником на иконе с тенью, а "Новый Звет" с цветовой гаммой исполненного художником рисунка.

Безусловно, что для автора "Ветхий Завет" указание, тень событий будущего, а "Новый Завет" - исполнение, восстановление истинного мика.

Слово "тень» в этом случае не упоминается и домжно иметь значение "амлегории", тем паче, что этот термин мы встречаем у апостола Павла и у других святых отцов, т.е. "тень" специальный термин, который используется в отношении миц "Ветхого Завета" и принадмежит к ряду таких терминов, как "амлегория", "мицо", "басня", "таинственные тени".

У Сабы встречаем также термин - «икона».

В этих суждениях Сабы дмя нас интересен тот факт, что

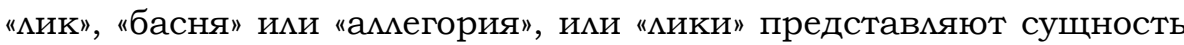
явлений.

Саба приводит в своих проповедях реальные, жизненные примеры. Следует отметить, что к этому методу прибегал сам Иоанн Златоуст в своих пастырских произведениях.

Он учитывал уровень подготовки паствы, его расположение и его жизненные примеры сопоставлял с библейскими явлениями и достигал чудесного эффекта.

Можно сказать, что проповеди целиком построены на последовательности таких изображений.

$\mathrm{K}$ каждой мысли, к каждому положению Саба, в качестве им^юстрации дает пример, взятый ими из библейских источников, или из жизни.

"Проповеди" Саба задумал как сборник по христологическому руководству, или как учебник. Первая же проповедь объясняет нам сущность церкви. 
Это и не удивительно, так как означенный сборник был предназначен дмя того, чтобы научить христианский церковный приход о назначении церкви.

В проповеди "Учение о церкви, или сути ее" полностью основана на выше перечисленныую мичностную систему.

Мы постараемся, выяснить суть церкви, ее мицо-символы.

Что представляет собой церковь в проповедях святых отцов?

Церковь есть: "Дом Господень", "тайное тело Христово" ("темо»), "Аик Господень", в церкви царствкет "Иисус Христос", "церковь - мицо, видимое в невидимом мире", "корабль, на котором верующие, живущие в жизненном водовороте плывут в тихую гавань", "духовная местница", "Аицо второго пришествия" и т.д.

В общем, церковь греческое слово и означает призыв или зов.

"Церковь Дом Господень и установленное Богом общество людей, которых объединяет вера" (Г. Кенчошвили. - Символы в христианском искусстве).

Проповедь начинается словами Соломона Мудрого:

"Блажен человек, который просыпается у ворот передо мной и смотрит на мой порог."

Автор задает вопрос:

"Где врата его, братья, где предстать нам перед его порогом?" (стр.21)

Этими словами Саба переносит внимание читателя к переоценке символического переосмысления Соломона, чтобы глубже понять его аммегорический смысл.

Соломоновы "врата" и "порог", символизируют церковные врата и церковный порог.

Символизириует тех - "кто всегда должен быть у дверей иеркви во иия будущего", - и достоин блаженства.

Автор разьясняет, что в соответствии со словами Соломона,

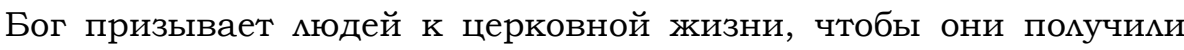
царство блаженства.

После того, как Саба разъясняет нам церковных прототипов "Ветхого Завета" и дает им символическо-алмегорическое толкование.

"Налил Бог Рай на Эдэм, поставил там Адама и оповестил его, сказав ему, ито еду с райских деревьев есть нельзя, ибо они олииетворяют суть добра и зла". 
Рай представлен прототипом церкви, а "всяческие райские плоды", Господь разрешил Адаму и Еве есть плоды от всякого дерева в саду, кроме плодов от дерева, которое называлось деревом познания добра и зма и прототипом Евангелия, которое должны "скушать, понять и принять как пищу духовного разума".

Запрещенный Богом плод греха - символ.

Человек должен отказаться от всего того, что запрещено Богом, нельзя не только видеть плод греха, но даже прикоснуться к нему.

"А посторонние и мирские слова и побуждения, в которых видны поедания запретных плодов райских, не схороним в сердцах, которых касаемся" - повествует проповедник.

"Посторонние и мирские слова и побуждения" домжны изгнать, чтобы грех не подчиним нас, что запрещеный Богом плод есть "фрукт непослушания", желание -"погребение сердец".

Саба учит, что мысль о греховном желании, равносильно греху. Акт входа человека в Рай, согмасно Сабы, можно так представить:

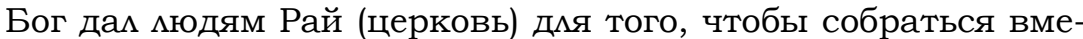
сте, и в то же время установия им, чтоб постигали они божественную мудрость

("Райские плоды"), служили истине, которая суть есть само Евангелие, а о грехах и мыслях о них (Вселенское слово", "плод запрета»), даже в сердцах не думали.

"Из Рая выходит одна река"-продолжает проповедник"которая разделяется на четыре рукава...Это мицо Святого Евангелия....которое орошает каждую часть земли."

Вышедшие из церкви четыре главы Евангелия (от Матфея, Марка, Ауки, Иоанна) прольет на землю божественную истину.

Кто "слышит заповеди Божьи" и "фрукты земные", не сьест их, он попадет в небесный рай, "где вечное бессмертие».

Если подпадем в рабство к дьяволу, также как Адам и Ева впали в рабство змеи и "заботами мирского разума" сьедим «запретный плод", не избежать нам вечных страданий.

Здесь видно великое значение Евангелия.Оно внушает цюдям, чтоб они не утонули в водовороте греха.

Здесь же встречаем еще одну парадигму, рассмотренную Сабой.

Это Ноев ковчег, как переосмысление прототипа Церкви. 
"Вослед за Церковъю был Ноев ковчег... Как взошел Ной на ковчег, и не внял никто словам Ноя, кроме семи домов его, и пришел nотоп и все потопил, кроме Ноя и его домочадиев." (стр.22)

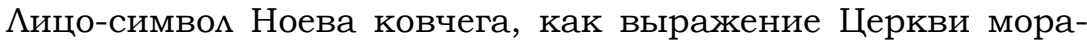
иистического характера, в отличие от выше рассмотренных миц Церкви и Рая, выше церкви и типы Рая, которые стремятся показать читателю божественную истину.

Ной включил в состав ковчега "семь домов" (семейств), которые амлегорически выражают семь сущностей чемовека:

«Ты тоже однажды войдешь в Церковь, с "семью домочадцами" твоими: сердцем -разумом, словом, глазом, ухом, языком, телом и запахом."

Человек все эти заповеди должен отчуждать от земных страстей.

Как Ною грозила гибель от наводнения, так и человеку грозят "буйства земные».

Как Ной нашел приют в ковчеге, также и человек должен найти приют в церкви.

"Стремись к церкви, как Ной стремился к ковчегу".

Здесь же ворон, которого Ной отпустил и мицо-символ изгнания черта, а голубь с оливковой ветвью, олицетворяет собой Святого Духа.

Һица-символы в "Учении" Сабы неисчерпаемы. Как видим, надуманное им- это попытка показать духовную сторону "Священного Писания"

Он опирался на существующую на грузинском языке богословскую митературу, на памятники духовной митературы, которые он исследовал по-научному.

References:

[1] Каландаришвили Э. Христианская проповедь и гомилии Сулхан-Саба Орбелиани, кафедра христианской культуры Тбилисского государственного университета, 2005 г.,

[2] Сумхан-Саба Орбелиани. Произведения., Том III, Тб., 1963 г.,

[3] «Новый Завет и Псалтирь", Стокгольм., 1992 г. 


\section{HOUSEHOLD PSYCHOLOGICAL PRINCIPLES IN THE WORKS OF NODAR DUMBADZE}

\section{Ardzhevanidze 1}

\section{Abstract}

Nodar Dumbadze was able to describe the deep inner world of man. He udeliyaet attention to issues such as the time and the perception of the person in Georgian literature. His characters carry with them the function of the inner psychology.

Keywords: psychology, personality, history, philosophy, psychological analysis, psychology, epoch, general psychological theory.

Психологизм в митературных произведениях - это детальный анализ с точки зрения историко-сравнительных, философских и психологических методов, к этому добавляются художественная интерпретация, исследование мировоззрения писателя и получаем детальный анализ произведения.

Фимологическое, в частности митературное исследование, его детальный анализ, требуют рассмотрения нескольких предпосылок с учетом исторических, философских и психологических факторов.

Исторические предпосылки охватывают осмысление исторически существующей эпохи, в той в которой живет писатель, или где создается произведение и, вдобавок дается анализ той эпохи, о героях которой создан роман, рассказ, стих ими создана поэма.

На указанную выше предпосылку могически опирается следующая философская предпосылка.

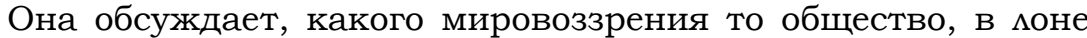
которого создано произведение.

Исследует мировоззрение писателя, так как это последнее тесно связано с мировоззрением героев произведения.

Формирование третьей - психологической предпосылки,

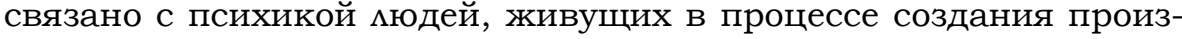

\footnotetext{
1rina Ardzhevanidze, Doctoral, Faculty of Humanities, Iakob Gogebashvili Telavi State University, Georgia.
} 
ведения и то, какой психики сам писатель - его создатель и какие психологические характеристики характеризует героев его произведения.

В случае мирического произведения, исследование проходит между

строкой и строфой, на фоне анализа существующего высказывания.

Определение психологических нюансов между мирическим героем и писателем - это определение вероятного расстояния.

Оно протекает по мере возможности, на фоне внутреннего состояния и духовности писателя.

Осмысливаем и то, кем являются в мичностном плане Нодар Думбадзе и его персонажи.

Аналитическое понимание художественной обертки, в каком-то роде трансформируется в ценности в увиденных выше перечисленных предпосылок.

Исторические, фимософские и психологические предпосылки определяют действие тех механизмов, с помощью которых мы входим в генетическое происхождение героя произведения, в его корни, и раскрываем закрытые слои, которые отождествцяют митературного героя, произведение, это ими то мицо, факт, персонажей, симвоцы.

\итература - это совокупность прозаических, поэтических и драматических произведений того или иного народа, эпохи ими всего человечества, вместе с культурно-историческим фоном, способствовавшим созданию этих произведений.

В нашем случае, в частности мы ведем речь о грузинской митературе XX-го века и о психологических штрихах в творчестве Нодара Думбадзе (1928-1984).

Считаем, что такое осмысление дает нам основание обратиться к исследованию понимания причин цемей высказываний митературными героеми писателя, и методологически обосновать, что существующие главные постулаты не смогут избежать вызова вышеперечисленных предпосымок.

\итературный процесс -это живой исторический процесс.

Это оживленная дискуссия проливает свет на каждое звено этой живой цепи и демает ясным детальный анализ произведения. 
Великий французский философ-позитивист, эстетик, писатель, историк и психолог, создатель культурно-исторической шкомы в искусствознании. Ипполит Адольф Тэн (1828-1893) говорил:

"Для познания произведений искусства, художника или группы художников необходимо полностью понять мировоззрение и обычаи той эпохи, $\kappa$ которой они принадлежат. Там мы найдем все объяснения. Там мы найдем первопричину, которая объяснит все остальное». (И. Тэн, 1989, 11)

Иитература и психология, в некотором роде, явцяются конкурентами.

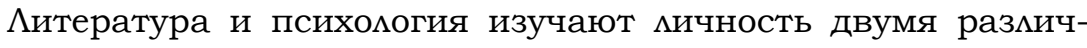
ными методами.

Иитературный метод - это метод искусства, метод психологии же - научный метод.

Это два принципиально отличающихся друг от друга подхода - ни один не кучше другого. У каждого из них свои преимущества и свои сторонники.

Можно сказать, что Нодар Думбадзе, при характеристике мичности использует бытовые психологические принципы.

Этот метод описал при написании "Аитературной трактерологиш" Теофраст, ученик Аристотеля.

Теофраст две тысячи мет назад использовал тот метод, который психологическая наука открыла мишь в XX-м веке.

Это метод обнаружения основных характерных черт - создание соответствующей ситуации, вызов и описание соответствующего поведения.

С того дня, как она была сформирована как независмая наука, и до сегодняшнего дня психология представляет арену споров дмя существенно обособленных точек зрений.

Общеприемлемой, единой психологическая системы пока еще не существует.

В настоящее время, психология опирается на категории восприятия, невосприятия, и поведения мичности.

Нодар Думбадзе глубоко всматривается в социальные события, в нутро внутреннего сопротивления и отражает типичный характер общественных сиц в призме собственной мичности.

Все художественные произведения писателя представляют субьективную и обьективную целостность, поэтому они отмечены меткой эпохи и индивидуальностью писателя. Эта суть отмечена в персонажах. 
Дия опредемения типа характера героя решающее значение имеют не всеобьемлющие, обще-повторяющиеся черты, а типичные черты, в которых проявляется внутренняя природа человека.

В произведениях Нодара Думбадзе, путем выдвижения на передний план его духовности полностью показан человеческий характер, его отношение к самому себе и его расположение к окружающей среде.

Его творчество, внутрення природа человека, его психика, глубокое проникновение в его духовный мир, использует дмя предначертания цели и новые художественные методы.

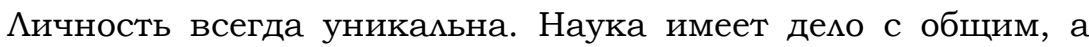
митература, в частности - с единицей.

У мичности, по мнению Гордона Уиммарда Олпота (18971967), американского психолога, разработчика теории черт мичности, имеются обще-психологические, а также дифференциально-психологические аспекты. Дифференциальная психология имеет дело с конкретной кичностью.

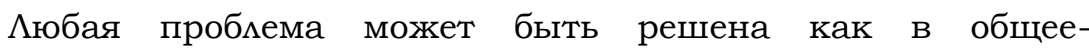
психологическом, так и в дифференциально-психологическом плане.

Ученый выделяет то, чему должна научиться психология у митературы:

1. В первую очередь, это стабимьные и твердые признаки точек зрения которая используется в свою пользу писателями еще раньше, чем учеными психологами.

2. Второе, что следует уяснить психологии, по мнению Г.У.ОАпота, это качественный, всеобьемлющий характер содержания.

3. В-третьих, психология должна заимствовать у митературы то, что должна сосредоточить внимание на индивидуальности, на конкретной мичности, а в общем не на абстрактной мичности.

Несмотря на такие заявления, Г.У. Олпот развивает общепсихомогическую теорию.

Каждая мичность создает уникальную систему мичностных черт со своей структурой, мотивацией, энергетикой и др.

Нодар Думбадзе смог глубоко и до мелочей описать внутренний мир человека.

Он уделяет внимание таким вопросвм, как восприятие времени и Аичности в грузинском митературоведении и его митературно-фимософское восприятие. 
На его героев возможена функция светлого показа внутренней психологии чемовека

Писатель принес в редакцию журнала "Дружба народов" рукопись рассказа "Я вижу солнце".

В произведении есть такой эпизод: мальчик и девочка - Хатия и Сосойя идут в соседнюю деревню, чтоб поменять одежду на кукурузную муку. Это тяжелые, голодные годы войны.

Всем трудно и крестьянин Бабило, который даст им переночевать у себя, утром бесплатно дает им целый мешок кукурузы.

Редактором журнала быма женщина. Она прочитала рукопись и сказала писателю:

«Нодар ВАадимирович, кто поверит, что крестьянин так за бесплатно дал кукурузу?"

Помню, вопрос меня озадачил. О данной проблему я не задумывался.

Я знал, что Бабимо по подсказке своей человеческой совести должен быц разделить кусок детям, в конце концов, я хотел, чтоб он так поступиц и потому я написал этот эпизод.

Я ответиц редактору:

«Не знаю, может и не поверят, но если хоть один чемовек мне поверит, это будет очень хорошо"

Повесть напечатали. Много писем я получиц, и не оказалось среди них ни одного не поверившего в это! (Н, Думбадзе, 1984,194)

Это один из самых известных эпизодов творческого и художественного решения писателя, и еще раз доказывает, что Нодару Думбадзе, как писателю,

Произведения Нодара Думбадзе не оставцяют впечатмения жанровых картин; повсюду вся фактура художественной ткани подчинена основной идее произведений и способствует ее воплощению.

Аиризм и драматизм, неподражаемый юмор, комизм многих описанных ситуаций - все вместе служит выражению размышлений автора о противопоставлении добра и зма, праве человека на счастье и мюбовь. 
References:

[1] Н. Думбадзе., Впечатления, письма, выступления, Тб., 1984.

[2] Н. Думбадзе., Избранные произведения, I, II, III, IV, Тб., 1989.

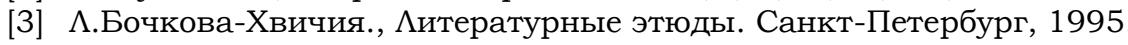

[4] Норакидзе В., Природа психологии и художественная митература, Тб., 1972.

[5] Тэн И., Фимософия искусства (на груз. яз.), Тб., 1989.

[6] Чкоидзе Н., Балиашвили М., Современники о Нодаре Думбадзе, Тб., 2007. 
THE WORLD OF THE FUTURE IN RAY BRADBURY'S CREATIVITY

Sh. Vakhtangishvili ${ }^{1}$

\begin{abstract}
Ray Bradbury's novel - "Usher II" starts and ends with quotation from Edgar Allan Poe's short story "Fall House Usher". In Bradbury's stories Edgar Poe's artistic world gains symbolic function with other fantastic works and "horror" genre which are referenced in the text. This world, in fact, symbolizes all unrealistic, fairy-fantastic, the Gothic artistic cultural heritage which according to Bradbury, represents threat of modern consumer, standardized society disappearing. In this artificial world is doomed any attempt to reconstruct what is symbolized by "Usher house" demolition.

Stendhal- the main hero of the work, whose 50000 books were burnt, decides to get revenge against the ideology of the society, which promote consumerism, mass cultural trend and try to forget literary lies and world of artistic muses.

His idea-plan is following: Stendhal builds a copy of Edgar Allan Poe's story "Fall House Usher" and challenges sterile, pragmatic society who does not have any idea about Edgar Poe and etc. Mr. Stendhal hosts them with Edgar Allan Poe's fantastic characters and final judgment is made by them. They die by these characters. The main character is saved and as long as he is alive, hope will exist to save Poe's world.

Ray Bradbury attacks the censors, which tried to inculcate united, the middle-class standards, since the fifties in all areas of American arts. The main treat for the writer is the threat of conformist, consumer, mass culture supremacy in society.
\end{abstract}

Keywords: mass culture, symbols, American policy, censorship, culture and equipment.

1Shorena Vakhtangishvili, Doctor of Philology, Department of Foreign Languages, Iakob Gogebashvili Telavi State University, Georgia. 
В творчестве Рэя Брэдбери мы часто встречаемся с проблематикой маскультуры. Её произведение "Ашер II" органически переплетено с проблематикой маскультуры. Массовая культура, как известно, направлена на конкретную мысль. Например, на приятное, на благоустройство, на радость. Это иногда подразумевает и коммерческие термины. Эрик Марэ дал определение массовой культуре, как совокупность объектов в "мировой культуре». В 60-ых годах XX века произошло "кристализование массовой культуры в Мировую культуру". Например, произведения высокой культуры, как известно, проходят, как исторический, так и культурный фильтры. Функцией произведений массовой культуры является их реализация.

Рэй Брэдбери является великой фигурой среди современных писателей в жанре научной фантастики и общей фантастики. Хотя сам писатель отрицает связь с научной фантастикой. Его произведения широко известны в мировой митературе. "Марсианские хроники" Рэя Брэдбери созданы в 1950г. Этот сборник печатался отдельно в разное время, и последний раз был напечатан под этим названием. Впервые произведение бымо напечатано в Соединённом Королевстве Великобритании. В сборник "The silver Locasts" внесены произведения фантастического жанра, объединённые в "Марсианских хрониках". В этот же сборник внесено произведение "Ашер II".

Следует отметить, что эта новемла органически не связана с другими новелмами, входящими в сборник. Название произведения вызывает ассоциации с известной новемлой "отца" фантастики - Эдгара А^лана По "Падение дома Ашеров". Как известно под влиянием По оказались, как его современники, так и американская проза XX века, например, техника По "иррационального иррационализма". Эта техника письменности широко используется в современной научной фантастической прозе. Этот способ используют писатели фантастики для научного опредемения психических сим и генетических мутаций. (Франк Герберт, Азимов и др.). Что касается романа Рэя Брэдбери "Марсианские хроники" это сборник связанных между собой новелц, а не роман. Брэдбери был всегда новелиистом, а не романистом. Входящие в этот цикл новелмы представляют собой независимые оконченные произведения, большинство которых можно считать извлеченными из контекста. Несмотря на то, что Брэдбери старается связать между собой основные новемлы, у автора не всегда получается их ху- 
дожественное объединение. Это также подтверждается фактом, что "Ашер II" был исключен из телевизионной версии "Марсианские хроники", т.к. эта новелма не имеет органической связи с другими произведениями этого цикла.

Таким образом, новеммы "Марсианские хроники" должны считаться "вариациями на тему", а не "главами" одного романа.

Брэдбери в своих письмах и интервью отрицает, что он явмяется представителем жанра научной прозы ('science fiction'), и своим единственным произведением этого жанра считает " $451^{\circ}$ по Фаренгейту". (I'm not a science fiction writer. I've only written one book that's sciebce fiction and that's "Fahrenheit 451" Branbury) [1.p.47]. Все его остальные произведения, включая "Марсианские хроники", согласно Брэдбери, принадлежат франтастическому жанру. "Mars is Fantastic, you see. It's not real, so it's fantasy (Bradbury)" [1.p.2].

Ранние новемлы писателя, которые опубликовывались в журнале "Weird Tales" принадмежали к жанру ужасов. Тональность новемл, входящих в "Марсианские хроники", варьирует соответственно, некоторые представляют собой эмементы фантастики и "ужасов", а некоторые имеют басенно-параболистический характер. Надо отметить, что жанровая специфика произведений Брэдбери, а также cor cordium его художественного метода определяется синтезом жанровых и стилистических признаков научной, фантастической прозы и "ужасов".

Некоторые исследователи, например, Дж. Марк, считают, что художественный мир Брэдбери оказался под вАиянием прозы По. Хотя надо отметить, что поэтика Брэдбери свойственно отличается от эстетической системы По. В его творчестве менее выражается мистицизм. Содержание, в отмичии от По, связано не со сферой подсознательной психики, а с общими тенденциями, симптоматическими признаками реальности, которые имеют место в политической, социальной и культурной жизни Америки после Второй Мировой войны.

Конечно же, новемла "Ашер II", входящая в "Марсовые хроники" получила своё название не под влиянием По. Это тот же случай, как если бы утверждать, что известный роман Джеймса Джойса "УАисс" получим своё название под влиянием Гомера.

Использование и оживление героев, цитат, мотивов "готических" новемл Эдгара По является пародированием некоторого пассажа. ГАавной целью автора в "Ашер II", была не реинтерпре- 
тация нюансов, а отражение Американской проблемы 1950 года в художественных образах. Автор перасно достиг своей цели, опубликовав известную новелцу "Ашер II".

Произведение написано в 1950 году. Действие происходит в 2005 году. ГАавным персонажем новемлы является Стендаль, который нанимает архитектора - мистера Бигеноу и заказывает ему построить точно такой же дом и сдемать точную копию дома, который великий Американский писатель Эдгар По описал в своём маленьком рассказе "Падение дома Ашеров".

Вправду, архитектор мистер Бигелоу создал точную копию дома Ашеров: здесь всё вокруг отуманено и ужасно, вокруг дома сплошная темнота, стоит холодный октябрь, земла неплодородная, мёртвая и стерильная. Здесь царит гнимая, нарушенная, осквернённая, отвратительная атмосфера.

Бигелоу не может понять, почему мистеру Стендалю понадобилось строение такого дома. Так как имена Ашера и Эдгар По он даже не слышал. По рассуждению Стендаля, это невежество вызвано событиями 1975 года, которые сложились в Американской реальности. Книги Эдгара По, Готорна, Аавкрафта, Амброза Бирса и, вообще вся митература жанра "фантастики" и "ужасов" была сожжена на пламени.

Всё это с начала 1950 года было результатом начала цензуры на детективные книги, фимьмы и т.д.

"Oh, it started very small. In 1950 and 60 it was a grain of sand. They began by controlling books of cartoons and then detective books and of course film, one way or another, one group or another, political bias, religious prejudice, union pressures... so they lined them up against a library wall one Sunday morning thirty years ago, in 1975" [2.p.5].

Свой план-замысел мистер Стендаль осуществиц с помощью Бигелоу. Основной целью Стендаля являлось отомстить за уничтожение книг и идей. "Дом Ашеров" как раз с этой целью и построиц Стендаль. Стендалю сожгли и уничтожили всю библиотеку, 50000 книг. Во время беседы с исследователем морального климата - Мистером Геретом выражает протест из-за фетишизма и преобладания реализма. Дця него более большой проблемой, чем уничтожение книг, является наличие такого общества, сознание которого устанавливает прагматическую, потребительскую ментальность. 
Дмя вызова и мести такому обществу Стендаль и решается организовать мероприятие. Он приглашает в дом Ашеров чценов общества по предотвращению фантастики. Гостей вместе с главным героем принимают герои и персонажи новемл Эдгара По. Наконец жители этого дома - сказочно-фантастические существа убивают всех гостей по отдельности.

Рэй Брэдбери данным пассажем выражает свою позицию против идеологов, которые устанавливают стандарты вкусов средних слоёв в государстве. Рэй Брэедбери выступал против цензуры, которая содействовала установке стандартов во всех сферах Американского искусства с 50-х годов. Конечно же, книги в Американской реальности никто не сжигал. Автор в своих произведениях предсказывает основу, которая будет сопровождать указанную цензуру. В тоже время, Брэдбери хорошо понимает, что цензура в этом случае является только одним частным симптомом более опасной тенденции, которая проявляется только в Американской реальности, а также в антикоммунистической истерии Сенатора Маккарта. Маккартизм для Брэдбери является самым ярким символом политических и социальных сил, которые содействуют становлению общих стандартов поведения, культуры, подавлению индивидуальной инициативы.

Дия автора главной опасностью явцяется установление конформистского потребительского общества, господство маскультуры. Эти тенденции явно отражаются в Американской реальности 1950 года. Такое общество Стендаль характеризует следующим образом: в таком напуганном обществе не остаётся места для ге-

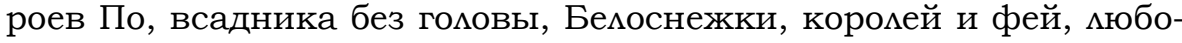
го Аитературного фантома и сказочных существ, созданных воображением и фантазией человека.

Брэдбери этим маленьким рассказом выступает против главной опасности общества, в котором воцаряются голый реамизм воображаемого мира, устанавливается потребительское общество и маскультура, уничтожаются прекрасные митературные обманы и фантазии и "подавляется искусство обмана".

References:

[1] Bradbury, Ray. Timless stories for Today and Tomorrow Bantam. 1952.

[2] Usher II.//http.Bradbury.ray/com

[3] Коренс Д.г. «Эдгар А^ан По» Книги. Эссе о классической американской китературе. Перевод Т. Котрикадзе Тб. 2004.

[4] Atterbery B. The Fabtasy Tradition in American Litriture Bloomington: indiana University Press, 1980. 


\title{
NITSSHEANISTIC MESSIANISM WITH GEORGIAN SIMBOLISTS
}

\author{
N. Kochloshvili ${ }^{1}$, T. Lapauri ${ }^{2}$
}

\section{Abstract}

In this science - related work talking about Nitssheanistic Messianism implications in Georgian Simbolists creativity. The simbolists creative way determined to some extent in Europe and Europian-trained philosophers school involved Grigol Robakidze's factor. After Grigol Robakidze lecture series the Georgian simbolists interested in Nitssheanistic Messianism preaching, it inerestingly reflected in their creative. In this rigard, special interest of the Giorgi Leonidze, Sergo Kldiashvili, Sandro Tsirekidze and Titsian Tabidze miniature posture patterns.

Keywords: Nitsshe, Messianism, Simbolisme, Blue horns, Miniature prose.

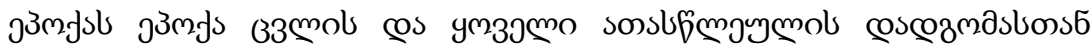

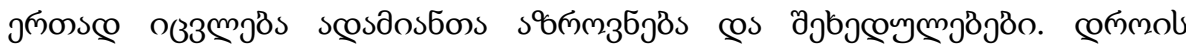

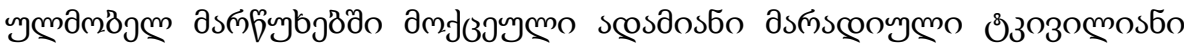

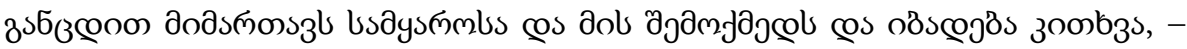

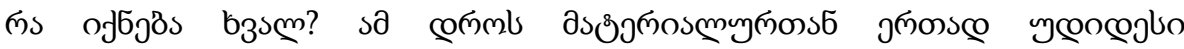

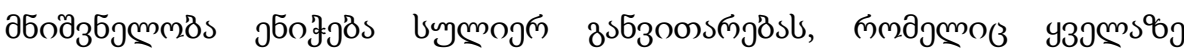

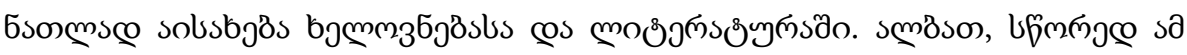

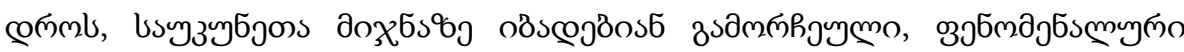

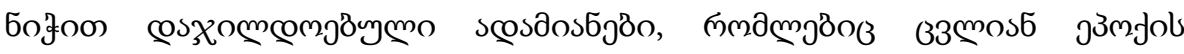

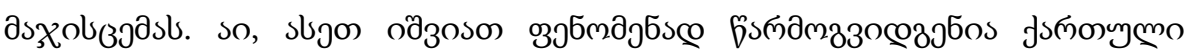

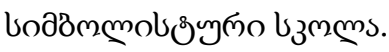

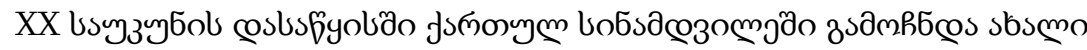

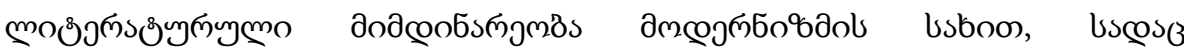

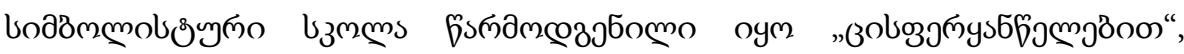

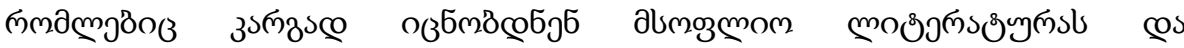

${ }^{1}$ Nino Kochloshvili, Professor at Iakob Gogebashvili, Department of Georgian Philology, Iakob Gogebashvili Telavi State University, Georgia.

2Tsitsino Lapauri, Doctoral Student, Faculty of Humanities, Iakob Gogebashvili Telavi State University, Georgia. 


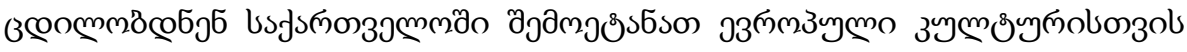

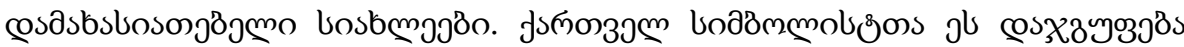

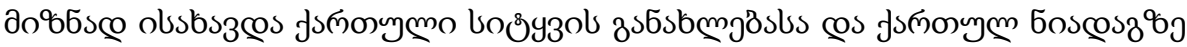

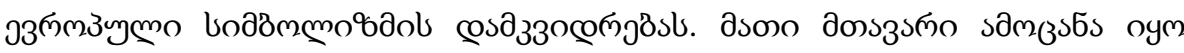

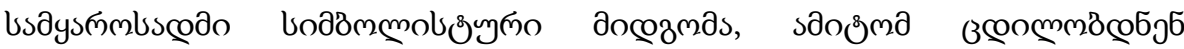

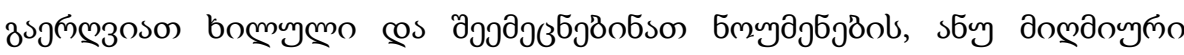

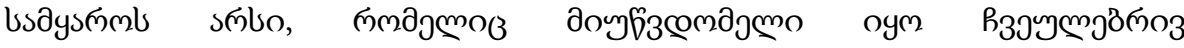

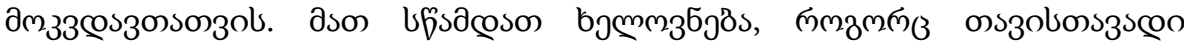

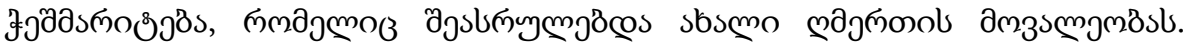

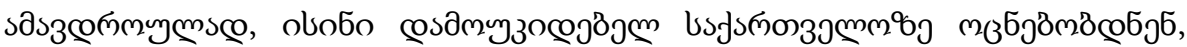

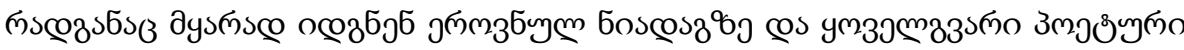

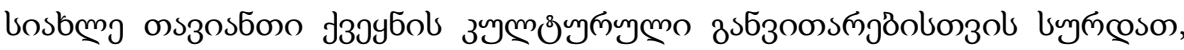

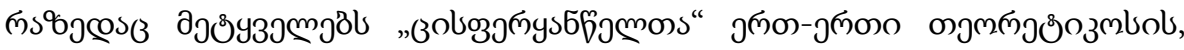

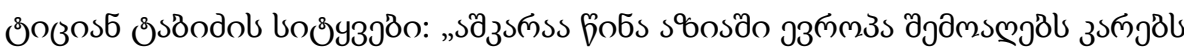

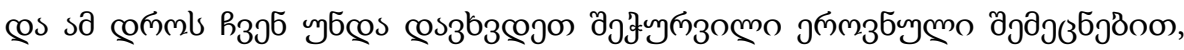

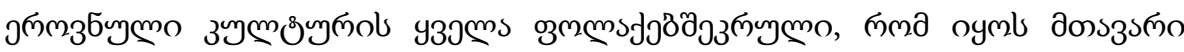

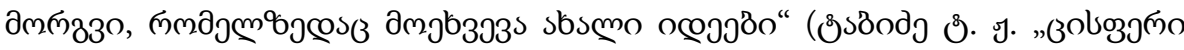
узб6рзо“", 1916).

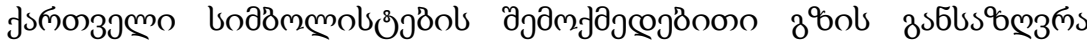
8ј

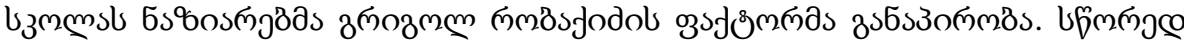

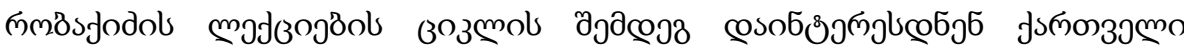

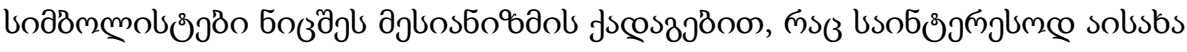

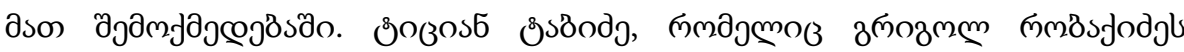

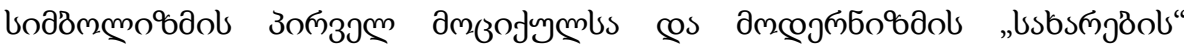

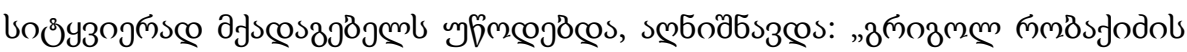

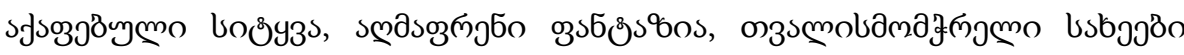

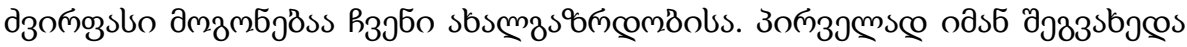

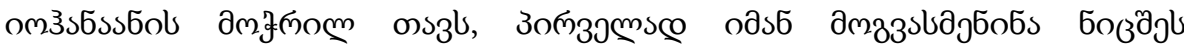

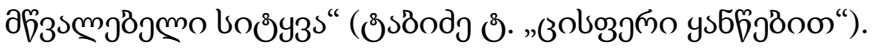

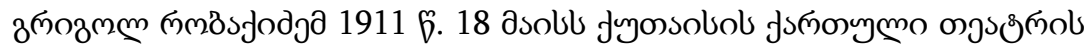

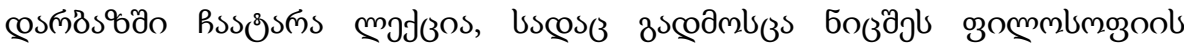

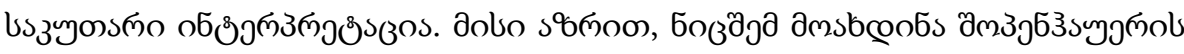

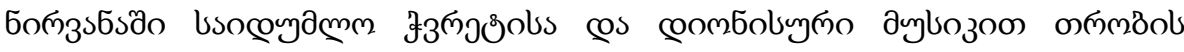

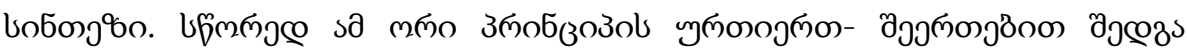

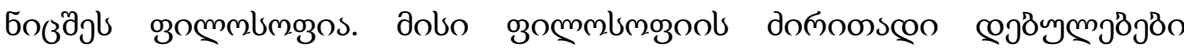




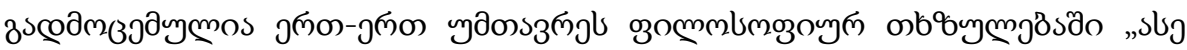

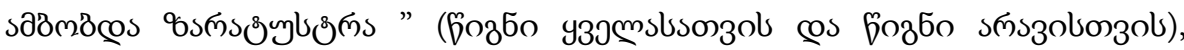

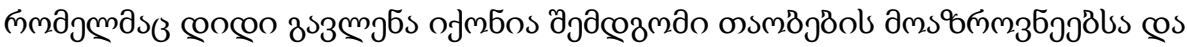

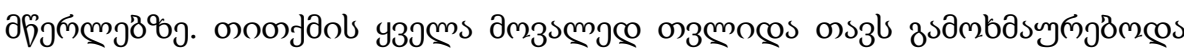

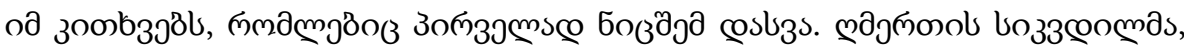

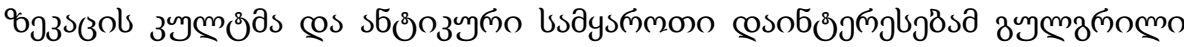

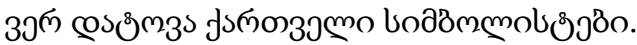

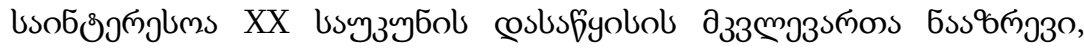

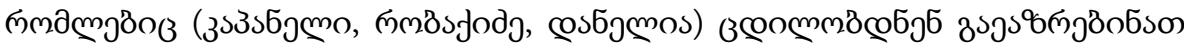

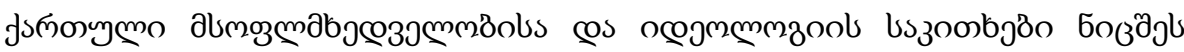

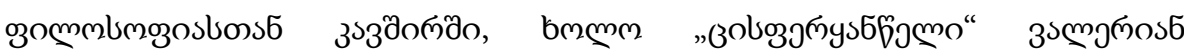

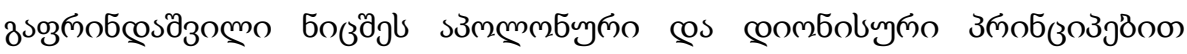

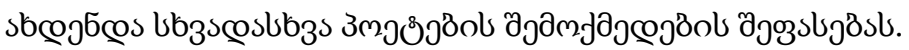

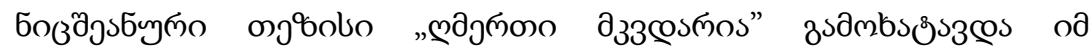

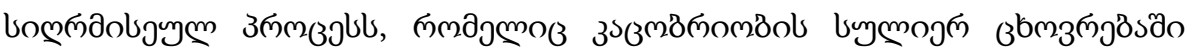

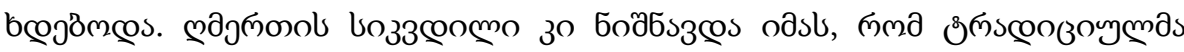

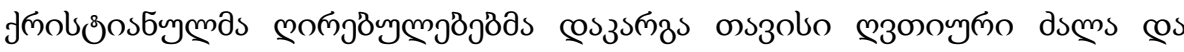

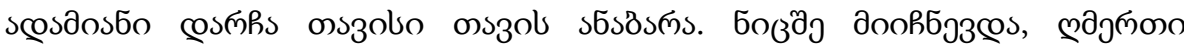

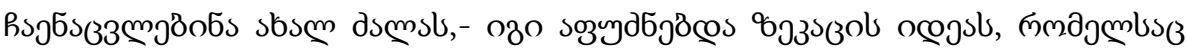

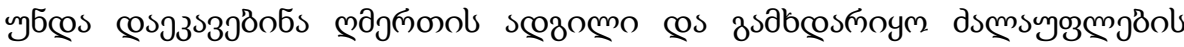

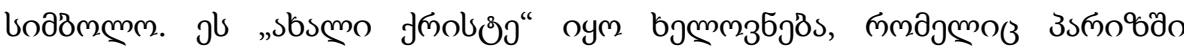

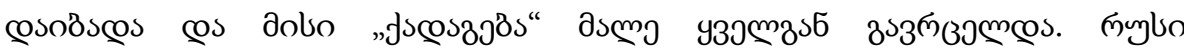

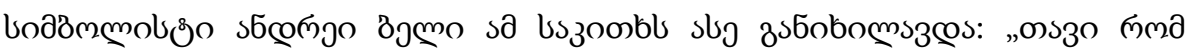

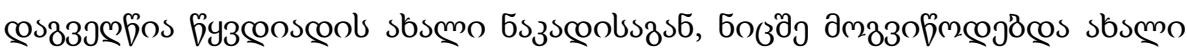

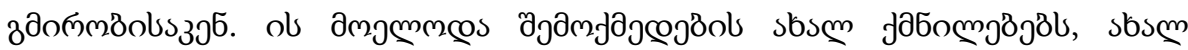

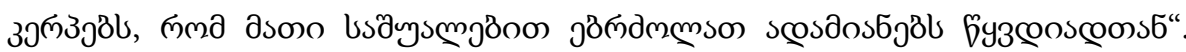

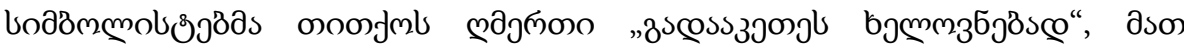

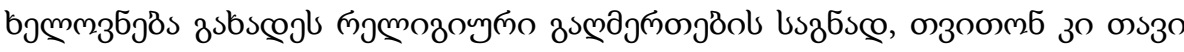

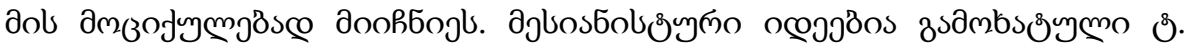

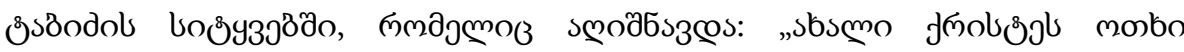

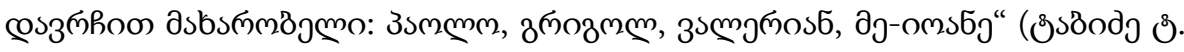

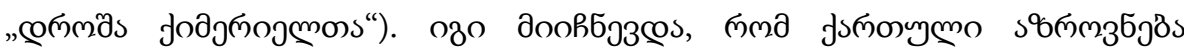

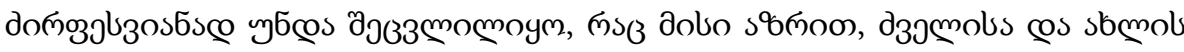

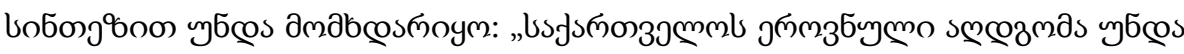

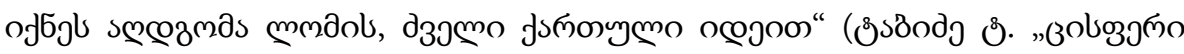

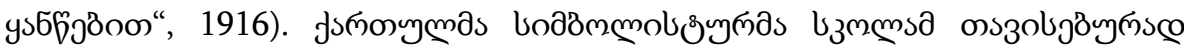




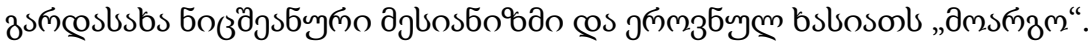

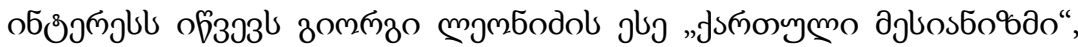

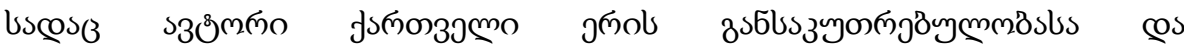

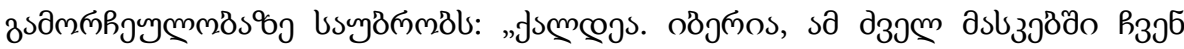

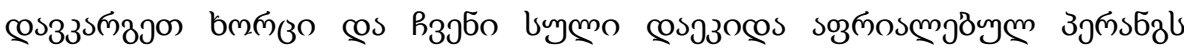

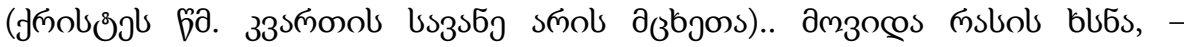

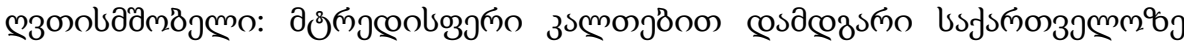

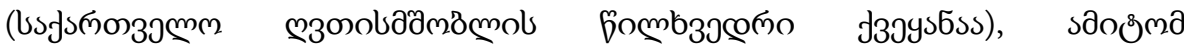

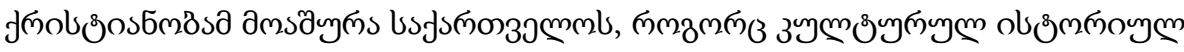
дуаззоœ๓

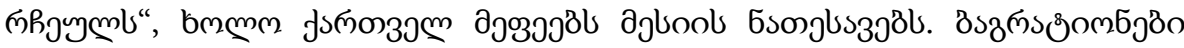

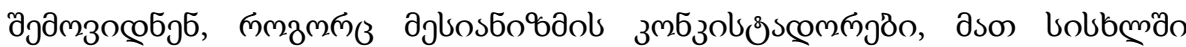

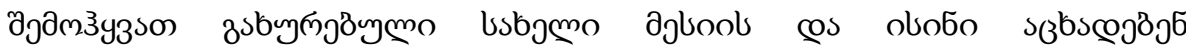

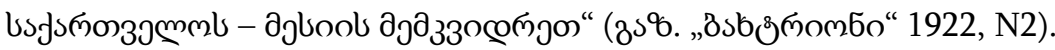

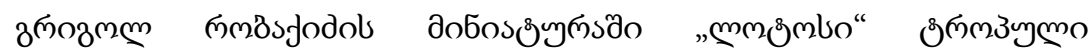

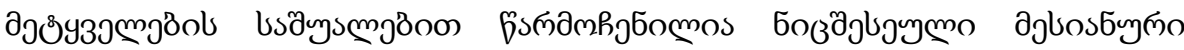

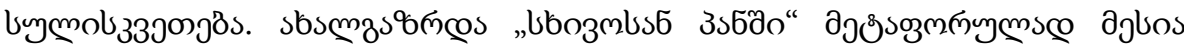

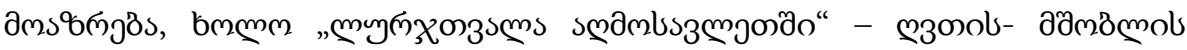

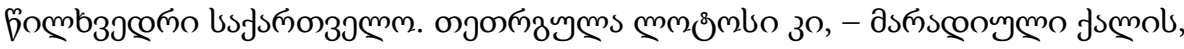

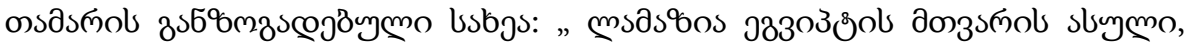

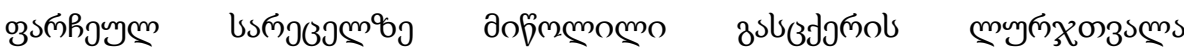

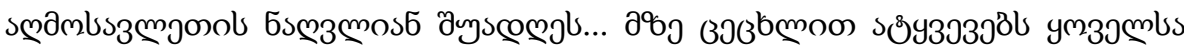

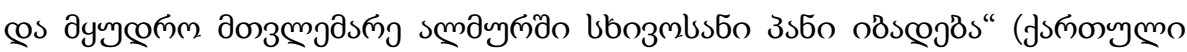

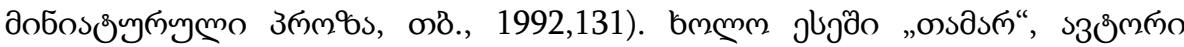

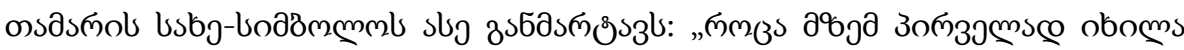

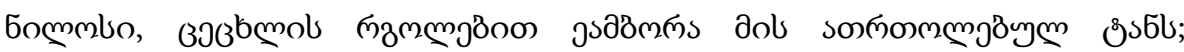

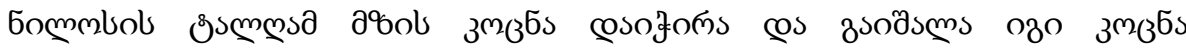

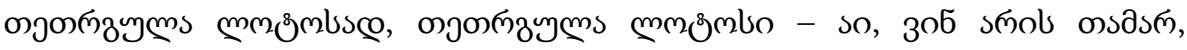

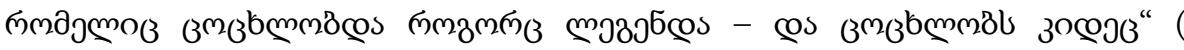

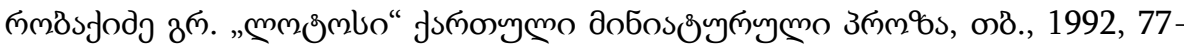
131).

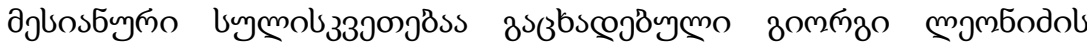

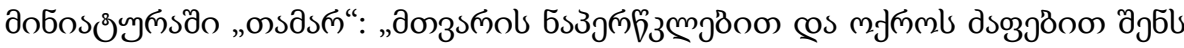

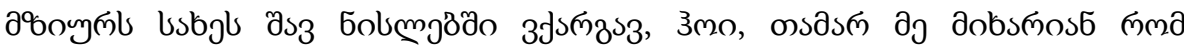

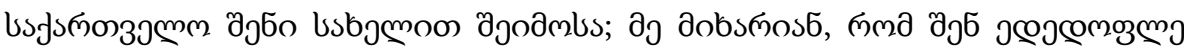

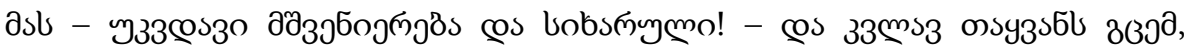




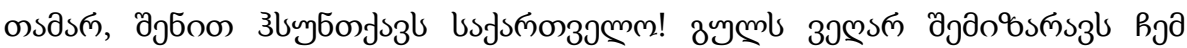

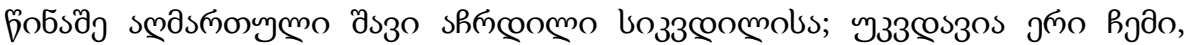

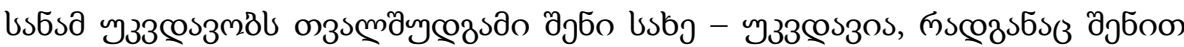

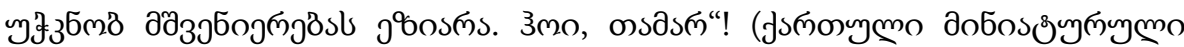
उलм\%ेs, 1992, 204).

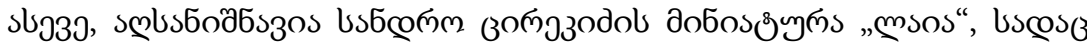

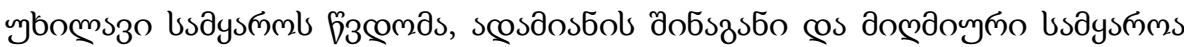

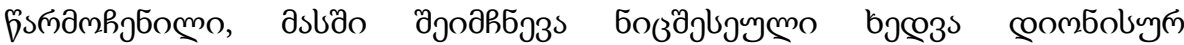

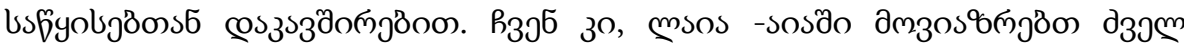

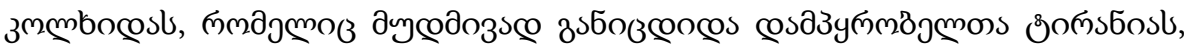

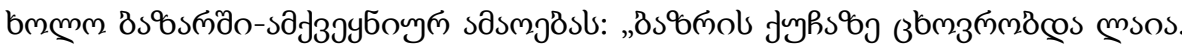

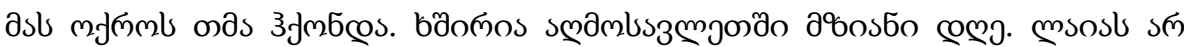

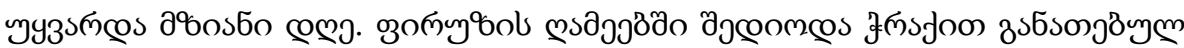

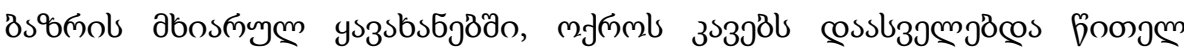

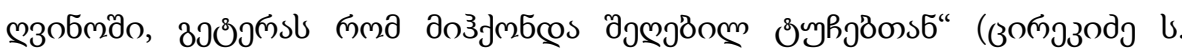

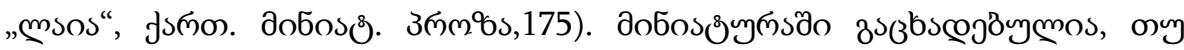

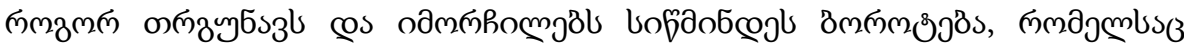

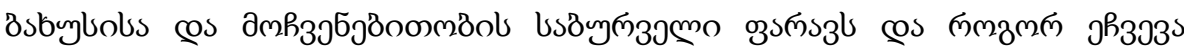

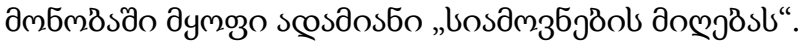

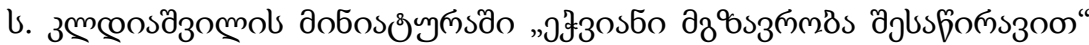

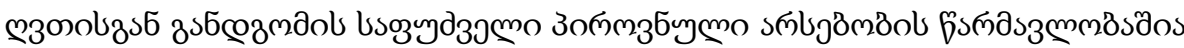

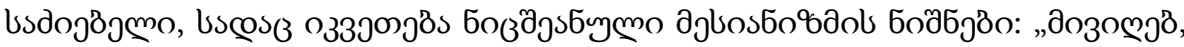

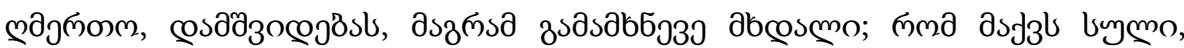

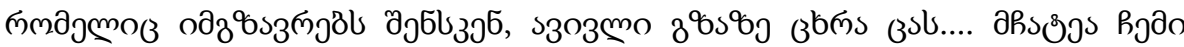

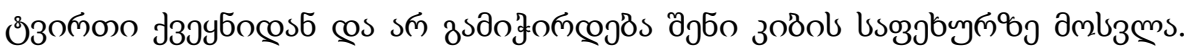

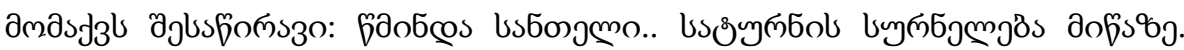

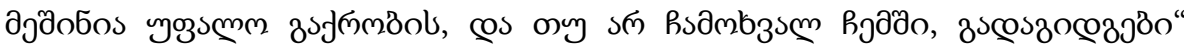

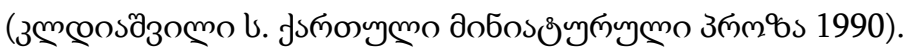

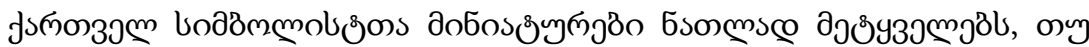

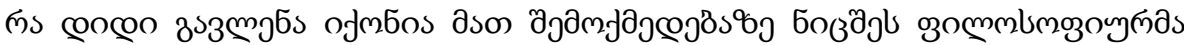

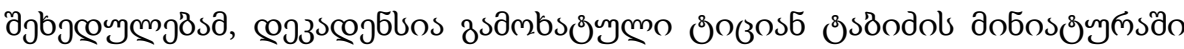

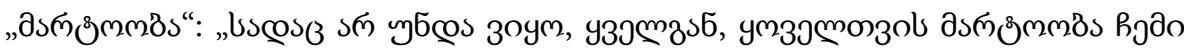

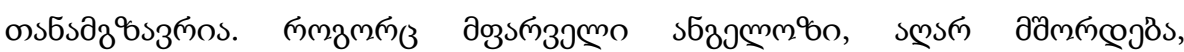

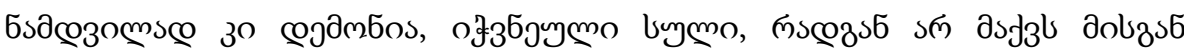

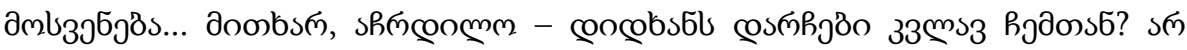

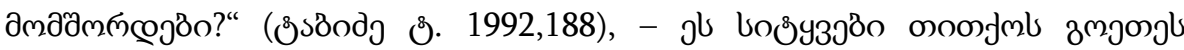




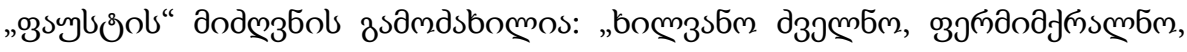

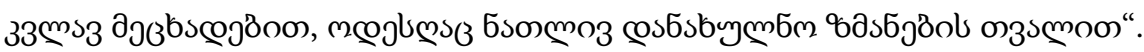

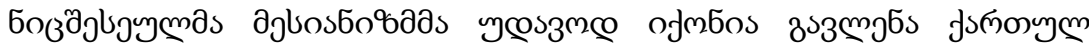

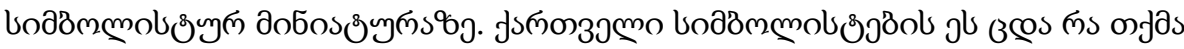

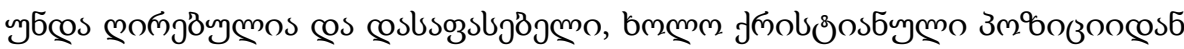

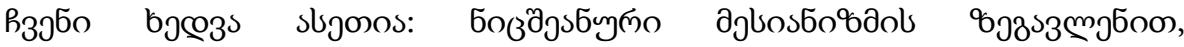

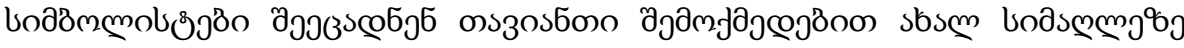

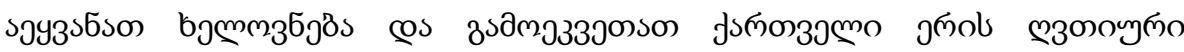
cosboð6ymgðs.

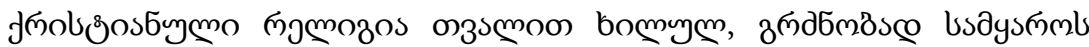

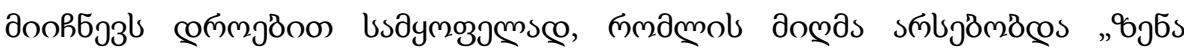

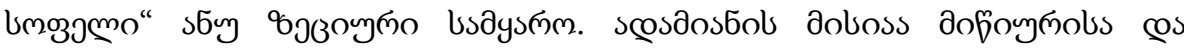

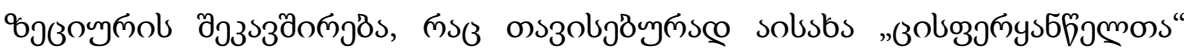

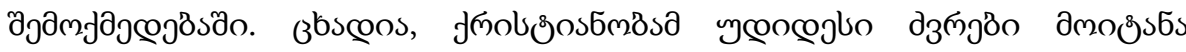

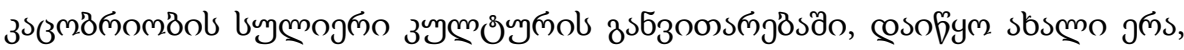

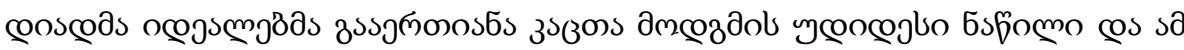

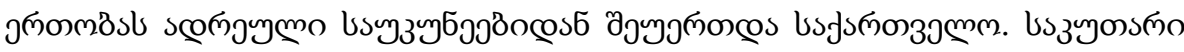

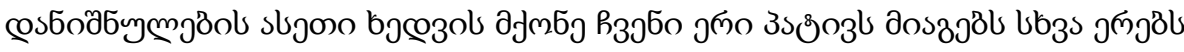

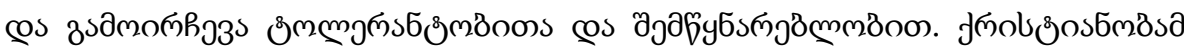

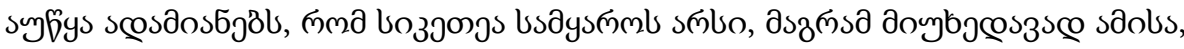

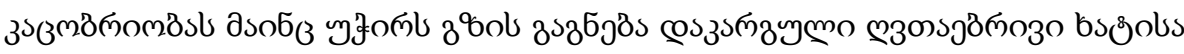

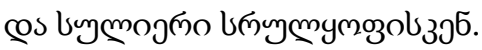

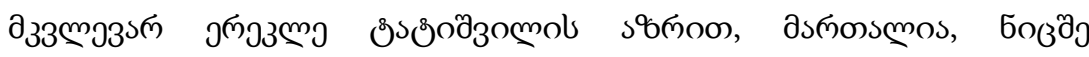

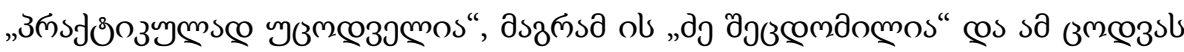

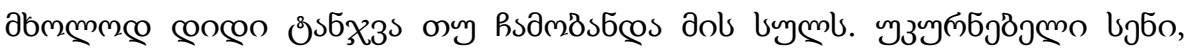

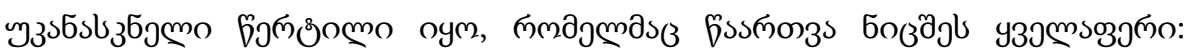

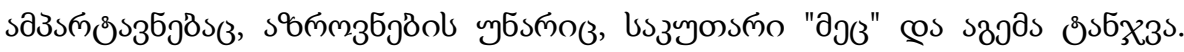

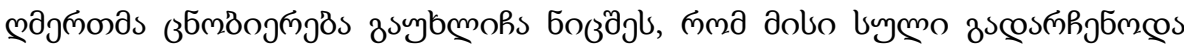

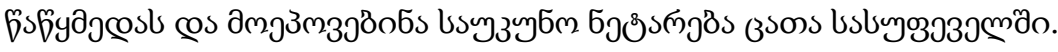

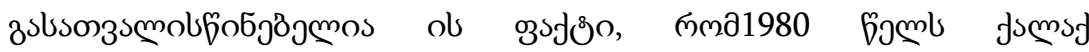

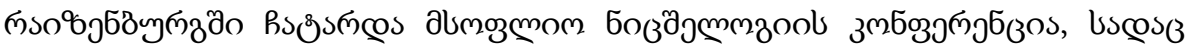

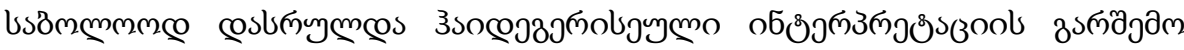

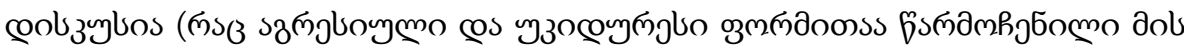

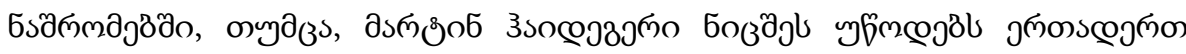

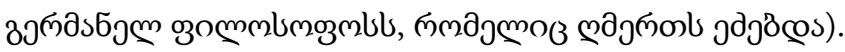


References:

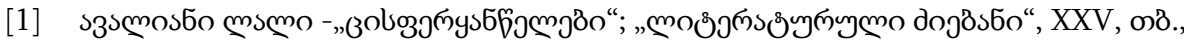
2004;

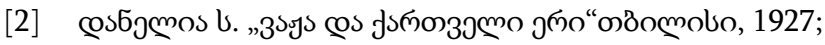

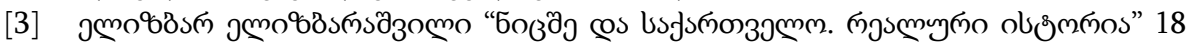
asobo, 2007 Øэмо,6узпм: http://comfortably.wordpress.com, Posted by:burusi, 19/04/2014;

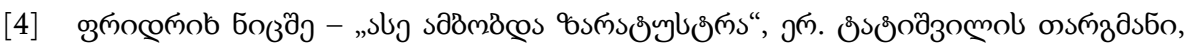

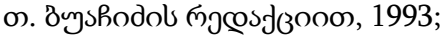

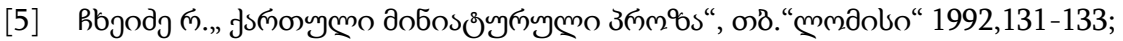

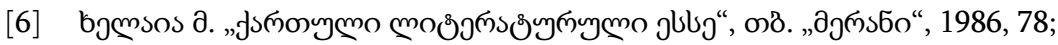

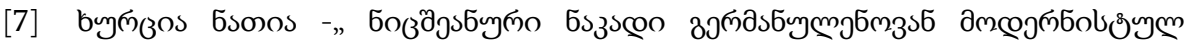

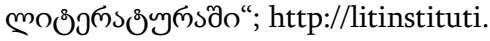




\section{FOR ONE KIND OF HYPOTACTIC CONSTRUCTION \\ IN THE GEORGIAN LANGUAGE}

\section{E. Pilashvili ${ }^{1}$}

\section{Abstract}

The article deals with the biverbal (two verbs) construction in Georgian Language. It is shown that the biverbal construction is a type of hypotactic construction. In particular, such sentence is seems to be the asyndetic compound sentence. Here are analyzed the following types of expressions: "I want to gift you", "I want to go" and "I try to raise" and etc. Decision is made based on discussion, under which is clear that such kind of sentence is asyndetic compound logically, structurally and semantically. This is due to semanticcontextual features and morpho-syntactic categories of "I want to gift you" types of expressions.

Keywords: Syntax, Biverbal predicate, Hypotaxis, Construction, Semantics.

In modern Georgian we often use sentences containing the structures like "I want to give you", "I want to go". For instance, "I want to give you, my Gabriel, one nice book" (Chavchavadze, 213, 2223). A group of researchers (e.g. L. Kvachadze) regards this kind of sentence as a complex one. Others (e.g. N. Kotinov) think that such sentences are simple ones and calls the predicate like "(I) want to give (you)" biverbal predicate. "Biverbal or a predicate with two verbs is a widely spread syntactic construction in modern Georgian. e.g. " $I$ want to make it higher", the first component of which is usually a modal verb in Georgian (I want, I can). The both components have a common subject in the sentence" [Kotinov, 1986, 98]. "We cannot regard a biverbal construction as a complex sentence in modern Georgian" [Kotinov, 1986, 101].

We regard this kind of a sentence in the Georgian language to be a complex sentence without a conjunction and not a simple one.

Let us consider the examples:

1. "I want to give you, my Gabriel, one nice book" (Chavchavadzde, 213, 22-23);

Shen, chemo Gabriel, ertikargitsignimindagachuqo.

${ }^{1}$ Elene Pilashvili, Assistant professor at Georgian Language and Literature Department, Faculty of the Humanities, Iakob Gogebashvili Telavi State University, Georgia. 
2.He wanted to find something more to eat (Vazha-Pshavela, 101, 3-4);

Kidevundoda, romshesachmeli ram epova.

3.And I thought that I'd go to Aghzevan for some salt (Chavchavadzde, 362, 2);

Me kimegona, aghzevansatscaval-metqimarilzed.

4.And I thought that you wanted something from me (Chavchavadzde, 207,9);

Me kimegonachemgangindarame.

5.Rain can shed my leaves all at once (Vazha-Pshavela, 34, 1314);

Tsvimassheudzlian, ertbashadchamomacalospotlebi.

Proceeding from the nature of the Georgian language, from the polypersonalism of a verb it is difficult to translate the Georgian sentences so as to show biverbal predicates in question. We have provided the adequate translation and also Georgian sentences in Latin transcription.

Our aim is to define what kind of a sentence it is according to its structure. It is obvious that it cannot be taken as a simple sentence as there are two predicates. And a simple sentence contains only one predicate.

In the Georgian sentence - "I want to give you, my Gabriel, one nice book", the conjunction that (rom)is omitted between the two predicates. Yet, it can be easily restored. The corresponding complex sentences with restored conjunctions will look like the following:

1. "I want to give you, my Gabriel, one nice book" (Chavchavadzde, 213, 22-23);

Shen, chemo Gabriel, ertikargitsigniminda, romgachuqo (The change is not reflected in the English Translation).

2.He wanted to find something to eat (Vazha-Pshavela, 101, 34);

Kidevundoda, romshesachmeli ram epova (The change is not reflected in the English Translation).

3. And I thought that I'd go to Aghzevan for some salt (Chavchavadzde, 362, 2);

Me kimegona, romaghzevansatscaval-metqimarilzed.

4.And I thought that you wanted something from me (Chavchavadzde, 207,9);

Me kimegona, romchemgangindarame.

5.Rain can shed my leaves all at once (Vazha-Pshavela, 34, 1314); 
Tsvimassheudzlian, romertbashadchamomacalospotlebi (The change is not reflected in the English Translation).

Now it is clear that these are sentences with hypotactic construction with the principal and the subordinate clauses.

The main clause is "The rain can", and "shed my leaves all together" is the subordinate one.

"The interrelation between the parts of a complex sentence is similar to that of between the words that are linked with a subordinate order where one word is principal and the other is subordinate, explaining the principal one" [Kvachadze. 1996,383].

In the above-given examples the linkage between the parts of a hypotactic structure is one-sided. That is why the parts of a complex sentence are not closely connected. This type of sentence is more independent in terms of logic, structure and semantics.

The parts of the hypotactic structure have a common word as well which is nominated in one part and is understood as the same or another member in the other part. For instance:

1.And I thoughtthat I'd go to Aghzevan for some salt (Chavchavadzde, 362, 2);

\section{Me kimegona, romaghzevansatscaval-metqimarilzed.}

"Me" ("I") of the Georgian sentence which is the object of the principal clausebecomes the subject in the subordinate clause) unlike "I" of the English where it is the subject. "Me" is the common member of the two clauses.

Me kimegona (аззодэзm5s) And I thought,

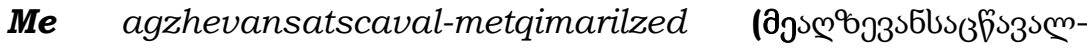

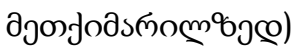

I'd go to Aghzevan for some salt.

One part of these sentences belongs to a principal clause and the other to the subordinate which has the same syntactic function as a subordinate sentence with a conjunction.

"And I thought I'd go to Aghzevan for some salt", in this sentence the second part of it "I'd go to Aghzevan for some salt" explains and specifies the general meaning of the subject of the principal clause "And I thought" which is expressed by a pronoun and provides it with precise content as a sentence with the conjunction "that" would do: And I thought that I'd goto Aghzevan for some salt".

It is noteworthy that the structure of this kind of sentences is invariable. The subordinate clause is at the end and it is impossible to replace it. Usage of verb forms is regular to a great extent. As for the correlative word suggesting the existence of a certain subordinate clause which serves asexplanatory and specifying, there is none of this kind in a subordinate clause. However, it can be easily restored. There may be a case when there is no correlative word either in prin- 
cipal or subordinate clause. Yet, either of them can be easily restored:

1. "I want to give you, my Gabriel, one nice book" (Chavchavadzde, 213, 22-23);

Shen, chemo Gabriel, ertikargitsignimindagachuqo.

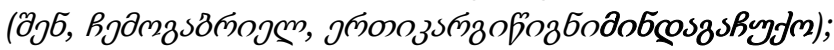
book";

"The thing is, my Gabriel, that I want to give you one nice

Shen, chemo Gabriel, mindais, romertikargicignimindagachuqo;

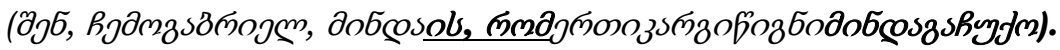

2.He wanted to find something to eat (Vazha-Pshavela, 101, 34);

Kidevundodashesachmeli ram epova;

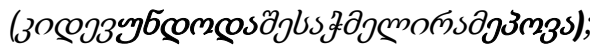

The thing that he wanted was to find something to eat;

Kidevundoda is, romshesachmeli ram epova;

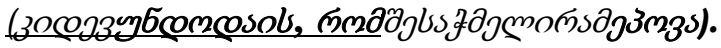

3.And I thoughtI'd go to Aghzevan for some salt (Chavchavadzde, 362, 2);

Me kimegona, aghzevansatscaval-metqimarilzed;

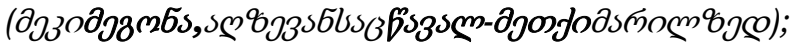

And I thought about the factthatI would go to Aghzevan for some salt;

Me kimegona is, romaghzevanswaval-metqimarilzed;

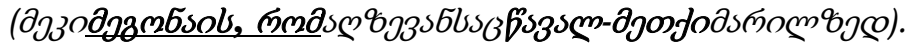

4.And I thought you wanted something from me (Chavchavadzde, 207,9);

Me kimegona, chemgangindarame;

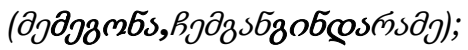

And I thought that you wanted something from me;

Memegona is, romchemgangindarame;

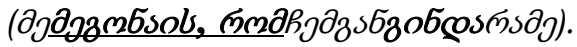

5.Rain can shed my leaves all at once (Vazha-Pshavela, 34, 1314);

Tsvimassheudzlianertbashadchamomacalospotlebi.

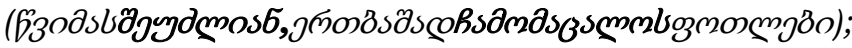


Rain can do a thing such as to shed my leaves all at once;

Tsvimassheudzlian is, romertbashadchamomacalospotlebi;

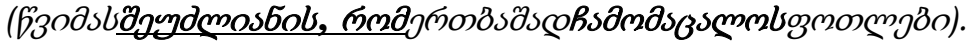

The above-said allows us to draw the following conclusion: this type of sentence can be considered as a complex sentence, a hypotactic structure without a subordinating conjunction in terms of logic, structure and semantics.

"A simple sentence is expressed with one word or the interlinked words. As for a complex sentence it consists of several simple sentences. This is the quality that marks the major difference between these two types of sentences" (Kvachadze, 1996,348).

To sum up, monopredicate and polypredicate constructions differ from each other both functionally and structurally. And it is evident from the above-given analysis that the sentence in question is not a simple sentence but a complex sentence without a conjunction.

References:

[1] Chavchavadze, I. (1985): Complete Works: Poems, Verses, Short-stories, Letters. Volume IV, Publishing House "Nakaduli", Tbilisi.

[2] Dzidziguri, Sh. (1973): Conjunctions in the Georgian Language. Tbilisi University Publishing House, Tbilisi.

[3] Ertelishvili, P. (1962): For the History of Complex Sentence in the Georgian Language. Tbilisi University Publishing House, Tbilisi.

[4] Geguchadze, L. (2005): The Question of Possible Relatedness of Grammar Tense Series and Tense Sequence in a Hypotactic Construction. Publishing House "Universal", Tbilisi.

[5] Gogolashvili, G. (2010): The Georgian Verb.Publishing House"Meridiani", Tbilisi.

[6] Kotinov, N. (1986): The Category of Mood and Several Other Issues of Syntax in Georgian. Publishing House "Ganatleba". Tbilisi.

[7] Kvachadze, L. (1996): Syntax of the Modern Georgian Language. Publishing House "Rubikoni", Tbilisi.

[8] Morphology of the Georgian (edited by G. Gogolashvili) (2011): Publishing House "Meridiani", Tbilisi.

[9] Peiqrishvili, J. (1996): Syntax of the Georgian Language. Publishing Center "Stamba". Kutaisi.

[10]Vazha-Pshavela (1964): Complete Works in Ten Volumes. Vol., V. Publishing House "Sabchota Saqartvelo". Tbilisi. 


\section{KARABAKH WAR REFLECTED IN LITERATURE}

\section{Ibrahimova ${ }^{1}$}

\section{Abstract}

At the end of the last century, Karabakh war launched by Armenian aggressors has resulted in a tragedy in Khojaly, the loss of $20 \%$ of the ancient lands of Azerbaijani, thousands of refugees deprived of their homes. In this article author paid close attention to Kharabag War on a perspective of the works of both Azerbaijani and Armenian authors.

Keywords: Karabakh, war, literature, slaughter, Khojali.

The war in Nagorni Karabakh which started in the 1991 continuous up today. The attack of Armenian troops precipitated the entrance of the Azerbaijan into war, a conflict which profoundly changed our life, deprived our people of their motherland, killed children and woman, captured many people. More than $20 \%$ of our land was occupied by Armenians. The line between right and wrong is so clear, the war news reported to the people by a host of our correspondents, the writers' visits to the front was consequently suffused with patriotism. The writers especially in tune with the prevailing Azeri attitudes were Nasiman Yaqublu ("Khocali slaughter"). Feride Hijran ("There is plundering in Karabakh") and others described the events witnessed by many of them. Their dispatches about the war in general and about the Karabakh war in particular were widely syndicated. The dispatches showed a folksiness. It was not the first description of Armenian atrocities in our literature. It was M.S.Ordubadi who in his "Bloody years" described armenians killing babies and old men. A.Abbasov in his novel "Zengezur" wrote about brutalized dashnaks who forced revolutioner Vahan to struggle with Shahmardan to the back of whom they tied boiling samovar, they couldn't calm down watching this "performance" and decided to throw them to the deep precipice.

Khodjali Slaughter became one of the most terrible war epi-

1Vusala Ibrahimova, Department of Foreign Languages, Ganja State University, Azerbaijan. 
sodes in the history of our nation. This bloody slaughter became the main theme of our poetry and prose. I.Efendiyev's "The Ruler and his daughter", A.Abbasov's "Hail" (Torrent), M.Tchemenli's "Snake's moll" are most truthful. The sacrifices made by the Azerbaijan soldiers in combat were great. The nation was instantly united by the Armenian attack on Karabakh. The obvious unjustness of this war keeps the nation in a cooperative mood. But all these are nothing in comparison with the armenian writer Zori Balayan's book "Inspiration of our Spirit" where he wrote about his own participation in Khojali Slaughter (Karabakh region).

"When we entered the house after the invasion of Khojali we saw 13-year-old azeri child nailed to the window. In order to stop the child's crying Khachatur stuffed his mouth with his mother's cut breast. Then I peeled skin from his head, breast and stomach, I looked at the watch: turkish child 7 minutes later died of blood loss, my spirit inspired of joy. Then Khacatur cut into pieces dead turkish child's body and threw to the dogs of the same origin. In the evening we did the same with other three turkish children. As an armenian I fulfilled my mission. I knew that each armenian will be proud of my action" $[1,89]$. Another armenian now living in Livan - David Xerdiyan in his book "For the Cross" writers "proudly": "In Cooley morning we had to pass through the bog near Dashbulag above which we made bridge of dead men. I didn't want to go over the dead. Podpolkovnik Ohanyan gave the signal not be afraid. I stepped 9-11year-old dead girl's breast and went on. My legs and trousers were in blood. So I passed pressing 1200 dead bodies". "On the $2^{\text {nd }}$ of March armenian grup "Gaflan" piled 2000 dead Turkish bodies near Khojali to put them on fire. In the last trace I saw 10-year-old girl wounded on the head and arms. Watching attentively, I saw that she was breathing. In spite of cold, hunger and wounds she was still breathing. I will never forget the eyes of this child struggling with the death. Then Tigranyan took her ears and threw to the dead bodies poured over by petrol. Then they put them on fire. Yells and cries of assistance help entreaty were heard from the fire" [2]. All these prooves the slaughter of Azeri peaceful people. Peculiar sounds of war. They clothe themselves in an unforgettable fierceness, just because born in danger and death. All these sounds, cries once heard in war are never forgotten. 
References:

[1] Balayan Zori. "Inspiration of our Spirit"

[2] <http: az. wikipedia. orgwikilivan>

[3] http: az. Wikipedia. Orgwikiaz\% C5\%9E\%99kil: Massachutsetts citation. Pdf> 


\title{
THE ROLE OF CLASS STAFF İN İMPROVEMENT OF LEARNING QUALITY
}

\author{
A. Guliyev1, G. Kazimova²
}

\begin{abstract}
The article deals with adaptation problem of mutual relations of junior primary schoolchildren, learning activity and at the sametime, improvement of learning quality. Here is shown that normal adaptation to the psychological and intellectual development, success of learning activity and acquisition percentage of junior primeschool children. Upbringing-learning-education should be correlatedwith potential and skills of human being.
\end{abstract}

Keywords: adaptation, school staff, education, student.

Адаптация социальной среды к себе в сущности - это удо-

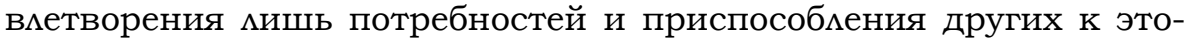
му. Такая форма адаптации нацеливает на новаторское решение проблемы. Таким образом, постепенно образуется новая система норм и ценностей. Такая форма адаптации характерна знаменитым Аюдям, обладающим силой воли, сильным характером. Такие Аюди выдвигают свои идеи, внушают их другим, умеют вести за собой других. Такая новаторская, творческая адаптация, в большинстве случаев, может быть полезно для больших групп, но дия малых групп, педагогических комлективов она может оказаться малоэффективным.

В младшем школьном возрасте в процессе адаптации и привыкании школьников друг к другу имеет особую роль общения их со сверстниками и взрослыми. В процессе общения друг с другом они выражают свои субъективные мнения, мысли и планы на будущее. В отличие от дошкольников в этом возрасте выдвигается на передний пман, не действия и предметная деятельность, а общения. Мцадшие школьники также умеют учитывать потребности, желания, настроения других и умеют демать созна-

\footnotetext{
1Allahverdi Guliyev, Ph.D in pedagogy, assistant professor, Ganja State University, Azerbaijan.

${ }^{2}$ Gunay Kazimova, Doctor of Philosophy in Psychology, Senior Lecturer, Ganja State University, Azerbaijan.
} 
тельный выбор. Это дает им возможность выбирать себе друга, товарища.

Воспитатели по разному подходят к проблеме адаптации мичности в социальной среде, колмективу. М.М.Гасанов отмечая особую роль общения, показывает, в процессе коммуникативной деятельности каждый из сторон участвует как субъект и как Аичность (1), а Я.А.Коменский отмечает, что система отношений носит двойственный характер, одно из которых направлено к пред-

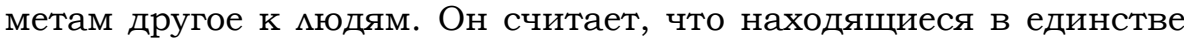
эти две системы отношений связаны с ведущим видом деятельности в разных возрастных периодах (2).

В педагогической митературе описываются факторы, которые негативно вцияют на процесс адаптации младших шкоцьников к школьной жизни. В их ряду перечисляются следующие: снижение успеваемости; специфика возрастного развития (смена ведущей деятельности); неспособность произвольно управлять своим поведением, вниманием, учебной работой; неумение приспосабливаться к школьной жизни (3).

В первый класс дети приходят из различных семей, с отличительными особенностями, способностями и уровнем подготовки. Объединение их в едином колмективе, восприятие и понимание друг друга и на этой основе адаптация к классному колмективу так же, дальнейшее развитие и формирование их мичности во многом зависит от того как организуется их учебновоспитательная работа. Учебная деятельность как ведущий вид деятельности занимает главное место в психологическом развитии и адаптации младших школьников к классному колмективу. Поэтому, изучение в единстве их учебной деятельности и взаимоотношений имеет важное значение. Отношение младших школьников к себе и другим формируется в процессе игровой, учебной и трудовой деятельности, которые имеют огромные воспитательные значения.

Я.А.Коменский отмечает, что специфические особенности детей формируются в деятельности. Под руководством учителей они активно включаются в жизнь колмектива, развивают свою познавательную деятельность, усиливают знание и социальные нормы. (4).

Учебная деятельность имеет широкие возможности в процессе адаптации учеников к классному колмективу. В процессе учебной деятельности ученики, усваивая научные знания также, 
приобретают знания в сфере взаимоотношений и навыки совместной деятельности.

Практика показывает, что большинство учителей различия обучение и воспитание мало уделяют внимание воспитательной функции учебной деятельности. Последнее время уделяется большое внимание тому, что ученикам не следует давать готовых знаний, что обучение должно служить развитию мышления. А.А. Али-заде по этому поводу отмечает, что должно ориентироваться не к механической памяти, а могическому мышлению. Поэтому поводу он пишет: “Современная концепция об образовании оценивает эту проблему новыми мерками, заявляя её как одно из трех функций обучения и дает особое значение развитию теоретическому мышлению учеников. (5).

Практика показывает, что введение дискуссий, полемики в процессе обучения повышает культуру общения учеников. Это положительно влияет на психическое развитие учеников, и они учатся работать в комлективе. Проблема вхождения младших школьников в дискуссии и полемики, её влияние на их психическое развитие изучено недостаточно. Этот процесс должен находиться под руководством учителей. В младшем школьном возрасте, особенно в первом классе, ещё нельзя говорить о формирующемся колмективе, по тому, что они только начинают узнавать друг друга. Исследования показывают, что образования первого впечатмения о других зависит и от объекта которого воспринимают и от психологической особенности субъекта, который воспринимает их.

Поведение младших школьников подчиняется ситуации деятельности. Так они ведут себя в соответствии с ситуацией, а это в свою очередь, создает условия дмя развития социальной установки.

Анализ педагогической митературы показывает, что в младшем школьной возрасте может различаться процесс восприятия и реальность. В большинстве случаев это зависит от ситуации и служит причиной неадекватному поведению. Негативное поведение их также, связано с наглядно-образным мышлением, который преобладает в этом возрасте.

Адаптация младших школьников педагогическому коммективу, учебной деятельности, сверстникам, школьной жизни зависит от сложных, взаимосвязанных друг с другом факторов. В зависимости от уровня адаптации к классному коммективу форми- 
руются у них мичностные качества, создаются для достижения успехов и терпения неудач. Здесь играет немаловажную роль семейное воспитание, отношение родителей к школе. Изучения особенностей взаимоотношений младших школьников со сверстниками имеет особое значение. Социальный статус в классном колмективе, отношения одноклассников к нм значительно влияют на формирование поведенческих мотивов в этом возрасте. Всё это позволяет сделать вывод о том, что есть прямая зависимость между статусом младших школьников в классном комлективе. И уровнем адаптации к нему. В этом возрасте учителя домжны учесть наряду с индивидуальными особенностями, также уровень адаптации их к школьному комлективу. Задачей учителей является обеспечение адаптации, к классному комлективу учитывая этих особенностей, воспитывая комлективизм и младших школьников. Обобщая вышесказанное можно сдемать такой вывод, что между направленностью мичности, мотивом поведения и уровнем адаптации младших школьников к классному комлективу есть прямая зависимость. Учёт этих особенностей позвоцяет учителям формировать комлектив и повысить качества обучения.

References:

[1] А^и-заде А.А. Психологические проблемы современной Азербайджанской школы. Баку, 1989 г.

[2] Ситаров В.А. Дидактика. М.: Академа, 2002.

[3] Сластенин В.А., Исаев И.Ф., Шиянов Е.Н. Педагогика. М.: Академа, 2000.

[4] Фельдштейн Д.И. Психология развития Аичности. М., 1998.

[5] Общение и формирование мичности школьников. Опыт экспериментального психологического исследования / Под редакцией А.А. Бодалева, Р.А. Кричевского; Науч-исслед. Инст-т общей и педагогической психомогии Акад.пед.наук СССР. М., 1987 


\title{
IMPLICIT METHODS FOR EXSPRESSION OF NEGATION IN MODERN RUSSIAN
}

\section{F. Agakishiyeva}

\begin{abstract}
In the article it is spoken about a means of negative implicit of modern Russian. It is mentioned that a means of negative explicit can not always make negatives. It is also shown in the article that negative implicit in modern Russian can be found out in the meanings of the words (e.g. refuse, deprive, abstain) and in the constructions (e.g. you understand so many things and so on). The author writes that negatives can be used openly in the words with positive meanings: these words are-have, used to say, it was very necessary and so on.
\end{abstract}

Keywords: negative implicit, negative explicit, emphatic ignorance, unreal modality.

Отрицание занимает особое место в традиционных и современных языковых и мыслительных категорий. В следствие многогранности понятия отрицания в языкознании сформировамись многочисленные мингвистические направцения, каждое из которых предлагает свое толкование категории отрицания и понимания его категориального содержания.

Отрицание может выражаться явным т.е. эксплицитным и не явным (скрытым, неявным) имплицитным способом.

Некоторые языковеды считают, что понятия утвердительности и отрицательности хотя и явцяются противоположными, но вместе с тем они взаимосвязаны, порождают друг друга, взаимно обусловлены. Т.Е. отрицание определённого явцения или фракта может быть в то же время импиицитным утверждением о других явлениях или фактах. Например, отвечая на вопрос "Дождь идёт?" (или "Идёт дождь?») отрицатемьно: "Нет, дождь не идёт", участник коммуникации может тем самым намекнуть на наличие осадка вообще, в виде снега, мивня или града. [4]

${ }^{1}$ Farida Agakishiyeva, Baku Eurasian University, Azerbaijan 
Известно, что имплицитные средства выражения отрицания не имеют грамматического показателя и относятся к средствам выражения отрицания, исходя исключительно из семантики, к тому же толкование этих слов, выражений производится через отрицание.

Средства выражения отрицания в разных языках чрезвычайно разнообразны, в частности синтаксически специфицированы. Так, в современном русском языке предикатное отрицание может отмичаться от отрицания при имени; разные видовременные формы глагола могут иметь разные отрицательные показатеми и т.д. [8].

Если остановиться на имплицитном отрицании, то в современном русском языке в рассмотрение следует включить также имплицитное отрицание в составе значения слов (таких, как, например, отказаться, воздержаться, мишен) и конструкций (например, много ты понимаешь! или чтобы я стала с ним связываться! Так я и повериц!). Термин отрицательное предложение обычно применяется к предможению, содержащему отрицание при финитном глаголе или предактиве, поскольку именно такое отрицание чаще всего оказывает влияние на структуру предложения в целом. Однако отрицание в составе мексического значения слова тоже может иметь синтаксические рефцексы.

Рассматривая конструкции с имплицитным отрицанием, можно заметить, что в современном русском языке имеются разнообразные языковые средства выражения идеи о том, что данное утверждение надо понимать в значении, противоположном тому, которое передается буквальным смыслом слов-так сказать, иронически. Например,

Есть из-за чего расстраиваться! Нашел, о чем говорить (кого приглашать)! Стоило из-за него божью птииу губить! (Чехов); Охота была ему жениться! Очень нужно мне за ним следить! Нужны мне ваши деньги! Много ты понимаешь! Только этого недоставало! Тебя тут только не хватало! Хорош друг! Велика важность! Стану я пса кормить! (Тургенев) Стала бы я стараться, если бы знала! Будет он молчать! [5]

Как видно из приведенных примеров, употребление в отрицательном смысле закрепляется за словами, выражающими отчетливо положительный признак: такие слова, как есть, стоимо, очень нужно, охота, много, хорош, велик, мегче всего приобретают противоположный смысл "вовсе нет", "совершенно не стоило", 
"совсем не стоицо", "совсем не нужно" и т.д. Слова стану, буду, выражающие твёрдое намерение, при экспрессии означают "совершенно не намерен".

Форма будущего времени у контактных глаголов дождаться, поймать, догнать, выражающая возможность, в конвенционально-ироническом высказывании означает полную невозможность: От вас дождешься! Таких поймаешь! Тебя догонишь=/тебя не догонишь/=/тебя нельзя догнать/.

Имплицитное отрицание выражает также конструкция "так ... и»: Так он тебе и сказал (скажет)! Так я ему и повериц (поверю)! Так они и дали (дадут) тебе эту премию! Так я и пошел (пойду)! Так я вас и побоялась (побоюсь)!

Такие слова и выражения как как же, как бы ни так, черта с два, держи карман <шире>, нечего сказать, жди, дожидайся показывает, что предшествующее высказывание следует понимать в противоположном смысле: Поехала (поедет) она с тобой, дожидайся!

Один из способов выразить отрицательное суждениериторический вопрос; он приблизительно равнозначен утверждению того предложения, которое получится, если вопросительное местоимение заменить на отрицательное (и, разумеется, добавить обязательное в русском языке не к сказуемому): Кто может объять необъятное? (К Прутков)='Никто не может объять необъятное'; И какой же русский не Аюбит быстрой езды !(Мёртвые ду-

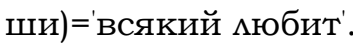

На модели вопросительного предможения основан целый ряд конвенциональных способов выражения эмфатического отвержения высказывания собеседника:

a) Да кому он нужен? Ну что ему сдемается? Да кто его презирает!

Высказывания этого типа выражают отрицательную реакцию на предшествующее высказывание, и этим они отличаются от риторических вопросов, которые не требуют диалогического контекста. Частица только в предложении (б), в отличии от предможений из (a), не может быть понято как обычный вопрос:

б) Зачем только держать на службе такую разгильдяйку? На базе вопросительного предложения строится оборот Откуда я знаю? который скужит для выражения незнания в качестве ответной реакции. В (в) возникает модальность невозможности: (в) Откуда я возьму такие деньги? [5;6;3] 
Конструкция с какой, какие служит для выражения возражения;

Какой он там ученый! Какие мы друзья! Какой же я посторонний! Какая уж там ирония! Какой тут отдых, когда дем столько? Какие там щи, если раков будем варить!

Значение недостижимости выражает конструкция "куда + датив":

Куда тебе, заморышу, браться за такое демо! [7]

Куда ему мюдей тянуть, он сам еме тянется! [1]

-Вот хотема капусту посадить $<\ldots>$, да куда мне, шов болит, голова кружится, того и гляди, в борозду сунусь! [2]

Конструкции из (г) выражают осуждение и сожаление:

(г) Охота же вам было жениться! Надо же было мне опоздать! Черт меня дернул ему возражать! Черт меня за язык тянуц!

Отрицание может выражаться ирреальной модальностью:

Чтобы я стала еще с ним связываться!

Имплицитное отрицание входит в состав значения многочисленных оборотов:

А мне-то что? =' мне до этого дело нет'; Ему-то что \='ему ничего плохого не будет'.

Отрицание вносится в подчиненную предикацию оборотом можно подумать:

Можно подумать, что ты этим довольна='я думаю, что на самом деле ты этим недовольна'

\section{References:}

[1] В.Гроссман.Жизнь и судьба (1960)

[2] Виктор Астафьев.Пролетный гусь (2000)

[3] Падучева Е.В. Семантические исследования: "Семантика времени и вида в русском языке. Семантика нарратива». М.: Языки русской культуры, 1996 г.

[4] С.Абдумлаев "Немецкий аффирматичес кий контекст", Издательство"XXI-YNE» OAO «Типография Красный Восток». Баку 2004

[5] Шмелев Д.Н. "Экспрессивно-иронические выражения и отрицательной оценки в современном русском языке" // Вопросы языкознания. 1958. № 6.

[6] Шведова Н.Ю. "Очерки по синтаксису русской разговорной речи, 1960.

[7] Ю.К.Олеша. В цирке (1928)

[8] Matti Miestamo Standard Negation. The Negation of Declarative Verbal Main Clauses inTypological Perspektive (Emperical Approaches to Language Typology 31). Berlin: Mouton de Gryyter.490). (2005). 
THE CONCEPT «FRIENDSHIP» AND ITS REFLECTION IN THE ENGLISH, RUSSIAN AND UZBEK PROVERBS

\section{Rahimova ${ }^{1}$}

\section{Abstract}

The article is devoted to the complex investigation of the concept "friendship" in comparative aspect on the material of three languages: Uzbek, Russian and English. The article analyzes and reveals similarities and differences in containing components of the concept “friendship' in Uzbek, Russian and English proverbs.

Keywords: concept "friendship", ethnic character, mentality, lingual culture, lingual world view, national specifics, paremiological fund, personal relations.

The concept "friendship" is a national cultural ground created by basic mental notions of communication. It should be noticed that such concepts as "friendship", "love", "family", "kindness", "hospitality" and "cooperation" are considered as the main concepts of any lingual culture. The concept "friendship" is a complicated but very interesting object of investigation. Moreover, if it is investigated on the material of several languages, it becomes more actual and significant. The concept "friendship" includes such notions as mentality, morality, ethics, spiritual world, culture and communication. Together these peculiarities create the concept "friendship" [2, p. 21].

Investigation of the concept "friendship" is one of those which haven't been totally studied. It conveys social, national, cultural information about language bearers. On the modern level of investigation this aspect becomes actual and necessary for deeper comprehension of the culture of a definite nation. Novelty of the article is vivid in comparative analysis of the concept "friendship" on the material of three languages: English, Russian and Uzbek. The material of research - proverbs of these three languages.

The object of investigation is lingual cultural concept "friendship" expressed by English, Russian and Uzbek proverbs. The sub-

\footnotetext{
${ }^{1}$ Iroda Rahimova, English teacher, scientific researcher of Samarkand State Architectural-Constructional Institute, Uzbekistan.
} 
ject of investigation became similarities and differences of the concept "friendship" in three analyzed languages.

The concept "friendship" reflects English, Russian, Uzbek lingual cultures as it is the complex of spiritual, moral and cultural peculiarities. The content of the concept "friendship" sometimes may be common in different languages. There is no any language which does not have the concept "friendship" as there is no any society where this concept doesn't exist. Friendship exists in any society and it defines human behavior and his personal qualities.

There is a significant idea that "any language represents definite way of conceptualization of surrounding world" [1, p. 322]. The centre of attention is not the language itself but language as the means of human communication or language in activity.

Any person belongs to a definite nation or ethnic group. That means that any human as a part of his nation or ethnos, leaves his reflection in lingual and communicative behavior of the ethnos he belongs to. Lingual comprehension is divided into a number of fragments of reality, which are understood as concepts. E.S. Kubryakova presents the following explanation of concept: "Concept is an operative unit of memory, mental lexicon, conceptual system and language of brain, world view, and measure of knowledge" [3, p. 11].

The content of the concept "friendship" also includes philosophical notions. In the process of our investigation there were revealed some types of friendship: friendship for pleasure, friendship for use, friendship for mercy. These are the main types of friendship. In fact, there also exist other subtypes of friendship: friendship between fellows, girls, old people, spouses, members of family, relatives, neighbors, classmates, group mates, guests, etc.

The semantics of this concept reflects the mark, which characterizes personality of a definite ethnos. The most frequent friendship is friendship for mercy. This is explained by the fact that friendship originally aimed at helping, assisting and doing kindness. Unfortunately, in the modern stage of human society development another type of friendship - friendship for getting profit becomes more and more usual. This type of friendship points at human's egoism.

In our investigation some proverbs about friendship have identical variants in all three analyzed languages. Semantic and structural content in them are totally similar:

Russian proverb: Аучше честный враг, чем коварный друг. Its analogue is English Proverb Better an open enemy than a false 
friend. Uzbek proverb Дуст ачиниб айтади, душман кулиб is semantically close to them but structurally is different. Such proverbs are called synonymic because they are similar in semantics but different in structure:

1)English proverb: Among friends all things are common.

Russian proverb: Жить заодно, делиться пополам.

Uzbek proverb: Икки булак - бир бутун.

2)English proverb: A true friend is the best possession.

Russian proverb: Друг - иенный клад, недругу никто не рад.

Uzbek proverb: Яхши дуст бойликдан афзалрок.

3)English proverb: In time of prosperity, friends will be plenty; in time of adversity, not one amongst twenty.

Russian proverb: Счастья не стало и друзей мало.

Uzbek proverb: Омад кетди, дустлар таркалди.

4)English proverb: Short (even) reckoning makes long friends.

Russian proverb: Будь друг, да без убытку.

Uzbek proverb: Дуст булсанг хам, хаддини бил.

5)English proverb: A broken friendship may be soldered, but will never be sound.

Russian proverb: Дружба - как стекло, сломаешь - не починишь (разобьешь - не склеишь).

Uzbek proverb: Синган дустлик хеи нарсага ярамайди.

6)English proverb: Old friends and old wine and old gold are the best.

Russian proverb: Одежда лучше новая, а друг - старый.

Uzbek proverb: Нарсанинг янгиси яхши, дустнинг - эскиси.

7)English proverb: A good friend is my nearest relation.

Russian proverb: Хороший друг, ито брат.

Uzbek proverb: Яхши дуст - биродардан якин.

8)English proverb: Old friends and old wine are best.

Russian proverb: Старый друг лучше новых двух.

Uzbek proverb: Эски дуст янгисидан афзалрок.

Some proverbs about friendship do not have analogues in other languages due to national-cultural specifics. For instance, in the Uzbek language there are many proverbs considering friendship as one of the most sacred values in human society. For such friendship a person should do whatever he can. The following proverbs have no analogues in other languages:

Икки дуст бирдан кура яхши, учтаси ундан хам афзал.

Дустликда яшасанг, хеи емонлик курмайсан. 
Бир маизни 40 киши еган.

In English proverbs about friendship a hint of freedom in friendly relations was revealed. Such proverbs were not found in Uzbek and Russian:

Friendship increases in visiting friends, but in visiting them seldom.

Little intermeddling makes good friends.

Friends are like fiddle-strings; they mustn't be screwed too tight.

In Russian proverbs there is intention to equality between friends:

Вяжись лычко с лычком, ремешок с ремешком.

И ты мне друг, и я тебе друг, да не оба вдруг.

Скажи мне кто твой друг, и я скажу кто ты.

But in all three languages there is call for real and faithful friendship, call for help to a person in any difficult situation:

English proverb: A friend in need is a friend indeed.

Russian proverb: Друг познается в беде.

Uzbek proverb: Хакикий дуст ёмон кунингда билинар.

So, we can conclude that the concept "friendship" demonstrates communicative behavior of people of a definite society which has peculiar national cultural specifics characterizing this definite nation, ethnic group or lingual society.

References:

[1] Апресян Ю.Д. Избранные труды. Том II. Интегральное описание языка и системная мексикография. Москва: Языки русской культуры, 1995. $766 \mathrm{c}$.

[2] Воркачев С.Г. Языковая мичность и концепт как базовые категории мингвокульрурологии // Ежегодные международные чтения памяти Н.С. Трубецкого 2000. Москва, 2000. С. 21-22.

[3] Кубрякова Е.С. Языковое сознание и языковая картина мира // Фимология и культура. Материалы 2-й междунар. конф. Ч. 3. Тамбов: Изд-во Тамб. ун-та, 1999. С.6-13. 


\section{B\&M Publishing}

Philology, literatures and linguistics: research articles, B\&M Publishing, San Francisco, California. 2016. 92 pp.

PQN 100

ISBN-10:1-941655-42-4

ISBN-13:978-1-941655-42-9 